\title{
Picketing the Homes of Public Officials
}

Although picketing has in the past been most frequently associated with labor disputes, it has served also to forward significant non-labor goals ${ }^{1}$ - most notably, those of civil rights advocates. ${ }^{2}$ In recent years, a variation on such "public issue" picketing has become increasingly prevalent; aggrieved citizens have moved their picket lines from government buildings to the private residences of public officials. ${ }^{3}$ Condemning this activity, one commentator has recently written:

1 See generally Annot., Nonlabor Picketing or Boycott, 93 A.L.R.2d 1284 (1964). See also cases collected in Note, Non-Labor Picketing and the Thornhill Case, 41 Colum. L. REv. 89 (1941).

2 See, e.g., NAACP v. Webb's City, Inc., 152 So. 2d 179 (Fla. D. Ct. App. 1963), rev'd for mootness, 376 U.S. 190 (1964); Hughes v. Superior Court, 339 U.S. 460 (1950); Young Adults for Progressive Action v. B. \& B. Cash Grocery Stores, 15l So. 2d 877 (Fla. D. Ct. App. 1963), appeal dismissed, 157 So. 2d 809 (Fla. 1963); Fair Share Organization v. Mitnick, 134 Ind. App. 675, 188 N.E.2d 840 (1963), transfer denied, 244 Ind. 117, 191 N.E.2d 100 (1963); Green v. Samuelson, 168 Md. 421, 178 Atl. 109 (1935); Anora Amusement Corp. v. Doe, 1'71 Misc. 279, 12 N.Y.S.2d 400 (1939); A. S. Beck Shoe Corp. v. Johnson, 153 Misc. 363, 274 N.Y. Supp. 946 (1934); Sumter v. Lewis, 241 S.C. 364, 128 S.E.2d 684 (1962); Tallahassee Theatres v. Due, 8 RACE REL. REP. 636 (1963).

3 See, e.g., Flores v. City and County of Denver, 122 Colo. 71, 220 P.2d 373 (1950) (disturbing the peace conviction reversed); People v. Levner, 30 N.Y.S.2d 487 (Magis. Ct. N.Y.C. 1941) (disorderly conduct conviction affirmed); Fawick Airflex v. Electrical Workers, 56 Ohio L. Abs. 426, 92 N.E.2d 446 (Ohio App. 1950), appeal dismissed for lack of debatable constitutional question, 154 Ohio St. 205, 93 N.E.2d 769 (1950) (contempt conviction of picketers of a judge's home). The home of Mayor Daley, in Chicago, has been picketed on several occasions: pickets protesting lack of action on school integration, Chicago SunTimes, August 15, 1963, p. 42, cols. 1-6; pickets protesting the rehiring of the superintendent of schools, Chicago Tribune, August 2, 1965, § 1, p. 8, col. 4; August 3, 1965, § 1, p. 1, col. 1, p. 10, cols. 3-5; August 4, 1965, § 1, p. 1, col. 3, p. 2, cols. 4-6; see also Wille, Mayor Daley Meets the Movement, The Nation, August 30, 1965, p. 92; pickets protesting destruction of trees for road project, Chicago Daily News, Sept. 23, 1965, p. 4, col. 6; civil rights picketers, Chicago Daily News, August 4, 1966, p. 3, cols. 3-7.

The homes of school board members in Chicago have been picketed. Chicago Sun-Times, August 15, 1963, p. 42, cols. 1-6. One school board president resigned after picketing of his home and sit-ins at his office. Chicago Sun-Times, August 17, 1963, p. 14, cols. 1-4, at col. 3. Pickets demanding the resignation of superintendent of schools Willis marched at his skyscraper apartment building. Chicago Sun-Times, August 16, 1963, p. 3, cols. 1-2, p. 26, cols. 2-6.

In San Francisco, Viet Nam war protestors picketed Governor Brown's residence. Life, Dec. 10, 1965, p. 114. Senator Dirksen's home in Pekin, Ill., was picketed by 550 union members protesting the Senator's filibustex against repeal of $\S 14-\mathrm{B}$ of the Taft-Hartley Act. Chicago Sunday Sun-Times, Feb. 2, 1966, p. 4, cols. 1-4. The home of the Jackson, Michigan, mayor has been picketed. Chicago Daily News, Sept. 2, 1966, p. 1, col. 7, p. 4, col. 7 . 
In the constitutional value scale, the quiet enjoyment and privacy of residential premises-even of the privately-owned homes of public officials-merits a higher priority than freedom of speech. A state or a municipality encounters no constitutional obstacle in drastically regulating picketing, whether labor or political, in residential areas, or even in prohibiting such activities."

Judicial authority, however, is not so clear-cut. Of four courts which have confronted picketing of public officials' homes, ${ }^{5}$ three have confined themselves to distinguishable fact situations in ruling against the picketers. ${ }^{6}$ The fourth has ruled in favor of their activity, stating:

The noise involved was incidental to a legitimate right, protected by the Constitution, to appeal to those in authority for redress of grievances by remonstrance, and such right must

In Milwaukee, the home of the chairman of the school board was picketed. Chicago Daily News, Oct. 20, 1965, p. 40, cols. 3-8, at col. 8. The home of an alderman was also picketed in Milwaukee. Milwaukee Journal, June 9, 1966, § 2, p. 1, cols. 6-9. A Milwaukee judge's home was picketed by civil rights workers following his refusal to resign from the segregated Eagles Club. Chicago Sun-Times, August 21, 1966, p. 42, col. 3; Time, Sept. 9, 1966, pp. 23-24.

In New York the home of a police officer was picketed by persons protesting his shooting of a Negro youth. Life, Dec. 3, 1965, pp. 90, 115. Gracie Mansion, residence of the mayor of New York City, has been picketed. Sunday New York Times, Oct. 11, 1964, § 1, p. 80, cols. 2-3. The White House is regularly picketed; judicial note was taken of this practice in Scott v. District of Columbia, 184 A.2d 849, 851 (1962).

In Milwaukee the residence of the Catholic archbishop was picketed. Chicago Daily News, Oct. 18, 1965, p. 1, cols. 5-8, p. 4, cols. 1-4. The home of the chairman of the board of directors of a hospital was picketed by a union. Hebrew Homes v. Davis, 38 Misc. 2d 173, 235 N.Y.S.2d 318 (S. Ct. 1962).

* Kamin, Residential Picketing and the First Amendment, 61 Nw. U.L. REv. 177, 18283 (1966) (hereinafter cited as Kamin, Picketing).

5 Flores v. City and County of Denver, 122 Colo. 71, 220 P.2d 373 (1951); Chicago v. Gant, Chicago Mun. Ct. No. 585,798 (1965) (unreported); People v. Levner, 30 N.Y.S.2d 487 (Magis. Ct. N.Y.C. 1941); Fawick Airflex v. Electrical Workers, 56 Ohio L. Abs. 426, 92 N.E.2d 446 (Ohio App.), appeal dismissed for lack of debatable constitutional question, 154 Ohio St. 205, 93 N.E.2d 769 (1950).

B In People v. Levner, 30 N.Y.S.2d 487 (Magis. Ct. N.Y.C. 1941), the court affirmed a disorderly conduct conviction on the basis of the dangers presented by the large crowd. It specifically did not pass on the legality of other instances of residential picketing. See text accompanying notes 129-31 infra. In Fawick, supra note 5, the defendants were found guilty of contempt for picketing a judge's home. Safeguarding of the judicial process is distinguishable as a special need. See, e.g., Cox v. Louisiana, 379 U.S. 559 (1965). See also, e.g., 18 U.S.C. $§ 1507$ (1964); MAss. ANv. LAws ch. 268, § 13A (1956). Moreover, conviction for contempt is a remedy peculiar to the official here being picketed. Gant, supra note 5, involved a conviction for disorderly conduct. See text accompanying notes $146 \& 152$ infra. As in Leoner, large crowds were involved. There was also a refusal to obey a police order to disperse. Clearly, none of these decisions necessarily extends to three or four quiet picketers parading before a non-judicial public official. 
be balanced against the right of the community to peace and quiet. $^{7}$

The purpose of this comment is to determine whether constitutional protections are afforded residential picketing, whether any restrictions may be placed on its practice, and if so, what form these restrictions might take. ${ }^{8}$

\section{The FramewORK}

Two lines of precedent press for consideration. State and federal court decisions involving labor residential picketing would for the most part urge prohibition of this activity. ${ }^{9}$ Similarly, Supreme Court decisions on non-labor picketing indicate the possibility of proscription. ${ }^{10}$ Neither line, however, is determinative. The labor cases cannot be indiscriminately applied to an activity which arises in a non-labor context. And the Supreme Court decisions, because they do not speak to this activity, do not dispose of the problems it poses.

\section{The Labor Cases}

With one exception, ${ }^{11}$ the courts have refused to sanction residential picketing in the course of labor disputes. However, their fealty in maintaining this position has been less than unwavering. Certainly one of the most emphatic denunciations of the practice was voiced in Pipe Machinery Co. v. DeMore. ${ }^{12}$ Since the appellants had only been direct-

7 Flores v. City and County of Denver, 122 Colo. 71, 77-78, 220 P.2d 373, 376 (1950). While picketing of a publicly owned residence may involve somewhat different considerations than that of a privately owned one, since the taxpayer's money supports it, that distinction is not present here. The following is the text of a letter from Phillip E. Jones, Senior Analyst, Colorado General Assembly Legislative Council, to the University of Chicago Law Review, July 11, 1966, on file in the Review office:

In 1949 and 1950, Colorado did not provide a state-owned home for its governor. Consequently, Governor Knous was living in a private residence at the time to which you refer.

Also, Colorado's governor receives a contingency fund appropriation of $\$ 10,000$ annually which may be spent at the sole discretion of the governor. Governor Knous could have used part of this fund for living expenses, but we do not know whether he used it in this manner or not. In any event, Governor Knous did not receive a specific appropriation for housing purposes in 1949 and 1950.

8 See generally Kamin, Picketing. For treatment of residential picketing under English and Canadian law, see Winkler, Picketing of Private Homes: the Anomalous Peaceful Picketing Clause, 2 Oscoode HaLl L.J. 437 (1963).

9 The labor residential picketing cases will be discussed in subsequent textual and footnote analysis. See generally cases collected in Teller, LAbor Dispitres and Coliective BARGAINING \& 115 (1940).

10 E.g., Cox v. Louisiana, 379 U.S. 559, 562-64 (1965); Cox v. Louisiana, 379 U.S. 536, 555,558 (1965).

11 Iron Molders' Union v. Allis-Chalmers Co., 166 Fed. 45 (7th Cir. 1908).

1276 N.E.2d 725 (1947). 
ing epithets against the non-striking employees, and therefore had not been conveying useful information about the strike, the court sustained an injunction issued to restrain their picketing. Reasoning further on broader grounds, the court made clear that it "did not wish it to be implied that the picketing of residences under any circumstances should be approved."13 The home is a "man's "castle" " and "his sanctuary," and residential picketing intrudes into its "quiet and peaceful environment. ..."14 Other courts, as well, have been firm in their disapprobation. ${ }^{15}$

This stance has not been universal. Thus, in United Electrical Workers $v$. Baldwin, ${ }^{16}$ the district court was leery of allowing the picketers' arrest for breach of the peace, recognizing the peaceful character of their activity:

It was in every sense of the word peaceful, and there was no use of force or threats. ... There was no attempt to block free ingress and egress from the homes, and no violence of any kind. ${ }^{17}$

Without state court authority to define the term "breach of the peace," however, the court felt compelled to refuse to issue an injunction restraining the picketers' arrest. ${ }^{18}$ Other decisions have displayed an ambivalence towards peaceful residential picketing, sustaining convictions because of the associated violence. ${ }^{19}$ A fairly old federal court

13 Id. at 727.

14 Ibid.

15 See, e.g., Hall v. Hawaiian Pineapple Co., 72 F. Supp. 533, 537 (D.C. Hawaii 1947); State y. Cooper, 205 Minn. 333, 285 N.W. 903 (1939); State v. Perry, 196 Minn. 481, 265 N.W. 302 (1986); State v. Zanker, 179 Minn. 355, 229 N.W. 311 (1930). In Petrucci v. Hogan, 5 Misc. 2d 480, 27 N.Y.S.2d 718 (Sup. Ct. 1941), the court enjoined residential picketing, holding that since the plaintiff civil servants were government employees and as such could not be coerced to join a union, the picketing was unlawful. In A. R. Barnes \& Co. v. Chicago Typographical Union, 232 Ill. 424, 83 N.E. 940 (1908), the trial court issued an injunction restraining the union, inter alia, from congregating about employees' homes or calling upon them. The decree was affirmed, but the decision is of slight value since the court felt that any picketing was illegal.

1667 F. Supp. 235 (D. Conn. 1946).

17 Id. at 242.

18 The court wanted to wait for a state court determination whether residential picketing constituted a breach of the peace. No judicial determination was forthcoming, but in the following year the legislature passed a law prohibiting the picketing of employees' domiciles. Conn. Gen. Stat. AnN. \& 31-120 (1960).

19 See, e.g., Busch Jewelry Co. v. United Retail Employees Union, 281 N.Y. 150, 22 N.E.2d 320 (1939). The Busch Jewelry strike and litigation is thoroughly documented in mariano, The Busch Jewelry Stores Labor Injunction (1940). See also, Miller v. Gallagher, 28 N.Y.S.2d 606, 611-12 (Sup. Ct. 1941). Miller cannot be given too much weight, since it relied on Thornhill v. Alabama, 310 U.S. 88 (1941), which first brought labor picketing within the ambit of free speech. Since then, the Thornhill doctrine has been contracted. See note 40 infra. 
decision, Iron Molders Union v. Allis-Chalmers Co., ${ }^{20}$ clearly allowed such activity. The court had before it an injunction which barred the unions "from ... picketing . . . the homes or boarding houses or residences of the said complainant's employees. . .."21 This decree was modified by adding after "picketing" the words "in a threatening manner." 22 Thus, the court acquiesced to peaceful residential picketing. ${ }^{23}$

Were inconsistency of language the only criticism that could be leveled against these labor decisions, one would be hard put to deny the combined weight of their holdings. There is a more definitive distinction at work here, however. Labor law is structured on an ability to identify the disputants, to isolate the grievances, and to reach agreements which render discernible changes in the pre-existing circumstances. Because of the relative definiteness and clarity of these goals, a viable system can operate to police and to protect the collective bargaining process. The consequence of this system is that prohibition of an activity such as residential picketing does not endanger the parity of the parties, since other well defined outlets of expression and action are guaranteed.

Non-labor picketing operates in a different framework. The government official represents a constituency whose desires are disparate and often contrary; the protestors themselves often are only loosely coalesced. Even if the disputants are distinct, their grievances are intertwined with political and social problems which cannot be solved by a carefully documented agreement, but only by a gradual process of change. Such a congeries of amorphous variables precludes a complex statutory scheme such as that erected to govern labor activity. ${ }^{24}$ Consequently, prohibition of non-labor picketing cannot be tempered by the guaranteed availability of other tactics.

Reliance, therefore, on the labor experience as a model for prohibi-

20166 Fed. 45 (7th Cir. 1908).

21 Id. at 47.

$22 I d$. at 52. But see criticism of the addition of these words, as applied to business, rather than residential, picketing in American Steel Foundries v. Tri-City Central Trades Council, 257 U.S. 184, 207 (1921).

23 In Southern Cal. Iron \& Steel Co. v. Amalgamated Ass'n of Iron Workers, 186 Cal. 604, 200 Pac. 1 (1921), a permanent injunction was issued restraining the union, inter alia, from going to the homes of employees to intimidate or threaten them. The appellate court made only minor modifications in the decree. Thus, it might be argued, as it was in the dissent in State v. Cooper, 205 Minn. 333, 285 N.W. 903 (1939), note 143 infra, that this means that peaceful picketing is allowable. However, the court seemed to indicate that it understood "intimidation" to encompass even peaceful picketing. See $186 \mathrm{Cal}$. at 608, 200 Pac. at 4.

24 Cf. Kalven, The Concept of the Public Forum: Cox v. Louisiana, 1965 SUP. CT. REv. 1, 28 (hereinafter cited as Kalven, The Public Forum). 
tion of non-labor residential picketing is bedeviled by a less than harmonious group of precedents and a dissimilar structure of group conflict on which to premise analogies. This, of course, is not to deny the relevance of the labor experience, but rather to emphasize that disapprobation of labor residential picketing does not necessarily compel the same conclusion in the non-labor field. ${ }^{25}$

\section{The Public Forum}

The streets and parks have traditionally served the needs of public discussion, as numerous Supreme Court decisions attest. ${ }^{26}$ Three recent cases have dealt with non-labor picketing, but like the labor cases, they are not dispositive of the issues surrounding residential picketing. Edwards v. South Carolina ${ }^{27}$ and the two Cox decisions ${ }^{28}$ are separated by only two years, yet their language suggests a shift in the Court's attitude. ${ }^{29}$ In the former, 187 placard-carrying demonstrators walked along the State House grounds to protest racial discrimination. Strongly sympathetic to such peaceful protest, an 8-1 Court reversed the picketers' conviction for breach of the peace: "South Carolina [had] infringed the petitioners' constitutionally protected rights of free speech, free assembly, and freedom to petition for redress of their grievances."30 The picketers, in fact, had "exercise[d] . . . basic constitutional rights in their most pristine and classic form." 31

25 As disputing reliance on labor law, see KAlveN, THE NEgro AND tHE FirST AMENDMENT 134-35 (1965); Kalven, The Public Forum 3 n.15; Konvrtz, Expanding LIBERTIEs 311 (1966); cf. Molofsky v. Bundy 34 U.S.L. WEEK 2582 (Baltimore Cir. Ct. April 16, 1966). But see the following decisions and articles, in which labor and non-labor picketing have been analogized explicitly, or implicitly, by use of traditional labor picketing rhetoric. Ex parte Lyons, 27 Cal. App. 2d 293, 299, 81 P.2d 190, 193 (1938); Julie Baking Co. v. Graymond, 152 Misc. 846, 847; 274 N.Y. Supp. 250, $251-52$ (Sup. Ct. 1934); Individual Retail Food Store Owners' Ass'n v. Penn Treaty Food Stores Ass'n, 33 Pa. D. \& C. 100, 110 (1988); Feinberg, Picketing, Free Speech, and "Labor Disputes," 17 N.Y.U.L. REv. 385 (1940); Note, Non-Labor Picketing and the Thornhill Case, $4 \mathrm{I}$ Colum. L. Rev. 89 (1941). See also Annot., 93 A.L.R.2d 1284, at 1290-91 (1964).

Professor Kamin, in Kamin, Picketing 182-205, deals at length with the analogy afforded by labor picketing, urging that reliance on labor precedent by proponents of non-labor residential picketing is misplaced, since the imprimatur of the free speech identification has long since been diluted. See note 40 infra. To foreclose this analogy, however, is not to resolve the question of non-labor picketing.

26 See, e.g., Edwards v. South Carolina, 372 U.S. 229 (1963); Kunz v. New York, 340 U.S. 290 (1951); Schneider v. State, 308 U.S. 147 (1939); Hague v. CIO, 307 U.S. 496 (1939); Lovell v. City of Griffin, 303 U.S. 444 (1938).

27372 U.S. 229 (1963).

28 Cox v. Louisianá, 379 U.S. 559 (1965); Cox v. Louisiana, 379 U.S. 536 (1965).

29 For a thorough analysis and comparison of the decisions, see Kalven, The Public Forum 4-10.

30372 U.S. 229, 285 (1963).

31 Ibid. 
Such clear language would appear to have firmly established non-labor picketing as an approved activity. In the two Cox decisions, however, the Court took a more restrictive view of this practice. Cox was arrested and charged with four offenses after leading a group of civil rights marchers into downtown Baton Rouge. ${ }^{32}$ The marchers' goal was to gather before the courthouse to protest the practice of segregation and the earlier arrest of twenty-three of their compatriots. While in the first decision the Court reversed Cox's conviction for blocking public passageways, ${ }^{33}$ it rejected his argument as to the constitutional protections afforded his activity with language as clear as that in Edwards, but far less felicitous in tone:

We emphatically reject the notion urged by the appellant that the First and Fourteenth Amendments afford the same kind of freedom to those who will communicate ideas by conduct such as patrolling, marching and picketing on streets and highways, as those amendments afford to those who communicate ideas by pure speech. ${ }^{34}$

This statement must, of course, be tempered by the actual disposition of the case, since the conviction was overturned. Yet the tenor of the majority opinion indicates at the least far less sympathy for the demonstrators' tactics than did that in Edwards, even allowing for the factual disparities between the two cases. ${ }^{35}$ The proponent of an activity such as residential picketing cannot therefore cite an unvarying judicial commitment to peaceful demonstrations in its defense.

The second Cox decision raises a further issue-that of the improper forum. The Court here considered Cox's conviction for violating a Louisiana statute prohibiting picketing of courthouses. ${ }^{36} \mathrm{Mr}$. Justice

32 The offenses were criminal conspiracy, disturbing the peace, obstructing public passageways, and courthouse picketing. Cox was acquitted of the first offense; the Court reversed the other three convictions.

83 The Court reasoned that the enforcement of the "obstructing public passages" statute was such that broad, undirected discretion was vested in local officials in the use of the streets. Thus such a system was equivalent to licensing, and Cox's freedom of speech and assembly were consequently unwarrantedly abridged. 379 U.S. at 557-58.

34379 U.S. at 555.

35 There were only 187 demonstrators in Edwards, while 2000 protestors marched to the courthouse in Cox. The marchers were on the street in Cox, while they were in a "horseshoe" area at the State House grounds in Edwards. Moreover, three offenses were involved in $\operatorname{Cox} I$, while Edwards concerned only a breach of the peace conviction. Despite these and other distinctions, the Court in $\operatorname{Cox} I$ noted the similarities between the two demonstrations. 379 U.S. at 548. Moreover, there still remains a basic difference in tone between Edwards and Cox $I$. As Professor Kalven observes: "[I]n a curious echo of the idiom of Edwards, [Mr. Justice Goldberg] wrote that the Court was not dealing [in Cox I] with speech 'in its pristine form' but with conduct of a totally different character." Kalven, The Public Forum 7.

36 LA. REv. Stat. 14:401 (Supp. 1962). 
Goldberg noted that the Baton Rouge police chief had given permission to patrol across from the courthouse. In effect, the officer defined the word "near" in the statute so as to remove the area across from the building from its compass. Having thereby given an imprimatur of legality to the demonstration, the authorities could not then order Cox and his followers to disperse because they had exceeded the time limit allotted them, since none of the statutes for which Cox was arrested authorized the drawing of such time lines. ${ }^{37}$

Despite this successful endeavor to absolve Cox, Mr. Justice Goldberg strongly supported the constitutionality of the statute. In its justification he cited the necessity for an impartial judiciary; he suggested that if a judge's decision happened to be in accord with the pleas of the demonstrators, a suspicion of acquiescence to these pleas might arise. While these justifications are not without difficulty, ${ }^{38}$ the importance of the opinion for residential picketing lies in the limits it suggests for the concept of the public forum. There may be certain sites so unsuited to use by protest groups that once a legislative determination has identified them, further traditionally considered variables of time and manner have no bearing.

Thus, the Cox decisions raise several important considerations in analyzing residential picketing. Non-labor picketing is labeled as "speech plus." 39 An identification associated with labor picketing,,0

37379 U.S. at $572-73$.

38 Ideally a legislature should also be free of undue pressures, even if it is properly more responsive to the public will than is the judiciary. Yet, as Edwards established, demonstrations before state legislatures are a welcome exercise of basic freedoms. Earlier decisions of the Court refusing to sustain contempt convictions for critical publications concerning pending or already decided cases, e.g., Pennekamp v. Florida, 328 U.S. 331 (1946), Bridges v. California, 314 U.S. 252 (1941), are not as easily reconciled as $\mathrm{Mr}$. Justice Goldberg maintains, see 379 U.S. 559, 563-64. It is not at all self-evident that the courthouse picketers would have any more influence on the judiciary than would vituperative utterances of newspaper editorialists or pamphleteers. Of course, Mr. Justice Goldberg's rationale for distinction-the broadness of the contempt power as compared to a narrow statute such as that in $\operatorname{Cox} I I-$ avoids these considerations.

39 It may well be that "pure speech" is an impossibility. The moment a word is realized in sound or in print, it impinges on the senses, even if only those of the speaker or the writer. Thus, the speech plus-pure speech distinction has come under attack. See Kalven, The Public Forum 23-25.

Whatever the failings of a conceptual framework drawn in terms of "pure speech" and "speech plus," it would appear that if dissemination of ideas or petition of government were the sole aims of the picketers, they could have achieved their ends by the more usual forms of expression and petition. The very fact that the residence is chosen as the site of the picketing would seem to indicate that the conduct aspect of such activitythe picket line-is intended to serve as more than merely the vehicle by which the picketers make public their grievance.

40 The free speech-picketing idiom was given constitutional sanction in Thornhill v. Alabama, 310 U.S. 88 (1941), when the Court brought peaceful labor picketing within the ambit of free speech. In a series of subsequent decisions, however, culminating in Inter- 
such a characterization recognizes that picketing is conduct as well as speech; that the physical presence of aggrieved citizens seeking to advance their cause makes picketing something more than the spoken or printed word. ${ }^{41}$ Cox II establishes that certain legislatively designated sites may be withdrawn from the public forum. The Court speaks of time, place, and manner, ${ }^{42}$ yet the anomaly is that variables of time and manner are irrelevant: the site-the courthouse-is simply unsuited for demonstrations.

While the Cox decisions and Edwards clearly set the background, they are not determinative of the residential picketing question. Edwards must be read in light of Cox. The first Cox case is of only general application, and the second, while more closely on point, cannot be read too broadly, for even in considering demonstrations only before public buildings, Mr. Justice Goldberg cautioned:

[E]ntirely different considerations would apply if, for example, the demonstrators were picketing to protest the actions of a mayor or other official of a city completely unrelated to any judicial proceedings, who just happened to have an office located in the courthouse building. ${ }^{43}$

Since prior decisions cannot resolve the residential picketing question, it is suggested that the basis for a solution which reasonably accommodates the interests of both sides is to be found by weighing the detriments incurred by the homeowner-public official ${ }^{44}$ against the benefits normally accruing to those who picket his residence. ${ }^{45}$

national Teamsters Union v. Vogt, Inc., 354 U.S. 284 (1957), the Court significantly narrowed the initially broad scope of Thornhill. See generally GREGORY, LABOR AND THE LAw, ch. 11 (1961). As a result, labor picketing may be quite freely regulated by the states today, Kalven, The Negro and THE First AMendment 134 (1965), although in fact federal pre-emption under the National Labor Relations Act operates so as to preclude significant state intervention into the regulation of picketing. Kamin, Picketing 197.

41 Cf. Hughes v. Superior Court, 339 U.S. 460, 464 (1950), in which a business was picketed by a group seeking proportional racial hiring: "Publication in a newspaper, or by distribution of circulars, may convey the same information or make the same charges as do those patrolling a picket line. But the very purpose of a picket line is to exert influences, and it produces consequences different from other modes of communication. The loyalties and responses evoked and enacted by picket lines are unlike those flowing from appeals by printed word."

42379 U.S. at 574.

43 Id. at 567.

44 In a statement made following the picketing of his home, and the homes of school board members, Chicago Mayor Richard J. Daley complained: "Surely this behavior is reprehensible, indecent and immoral . . . . It's a much different thing to picket a man's home then (sic) picketing his office. It becomes a question of affecting one's family." Chicago Sun-Times, Aug. 17, 1963, p. 14, cols. 1-4.

45 Cf. United Electrical Workers v. Baldwin, 67 F. Supp. 235, 242 (D. Conn. 1946); Strberman, Crisis in BLack and White 330 (1964). 
The Detriments and the Benefits

\section{The Nuisance Factor}

Probably the most immediate reactions engendered by residential picketing are that it constitutes a nuisance and an invasion of privacy. Two Supreme Court decisions illustrate the balancing which has occurred when a claim to use of the streets is weighed against the nuisance created by that use. In Schneider v. State ${ }^{46}$ the Court had before it ordinances whose alleged aim was to eliminate litter by either prohibiting, or requiring a permit for, the distribution of handbills on the streets. In striking down three of these ordinances, the Court reasoned that "the purpose to keep the streets clean and of good appearance is insufficient to justify an ordinance which prohibits a person rightfully on a public street from handing literature to one willing to receive it." 47 Clearly, then, the aim of deterring litter cannot justify proscription of street-corner pamphleteering. Kovacs $v$. Cooper ${ }^{48}$ presented a related situation. A Trenton, New Jersey, ordinance forbade the operation of loudspeaker trucks on the city streets. The appellant was convicted of its violation, having used such a device to comment on a labor dispute then in progress. In sustaining the conviction, the Court maintained that "constitutional protection" could not be called forth to protect "what those charged with public welfare reasonably think is a nuisance when easy means of publicity are open." will apparently justify limiting the use of the streets.

46308 U.S. 147 (1939).

$47 \mathrm{Id}$. at 162 .

48336 U.S. 77 (1949).

49 Id. at 88-89.

50 Two cases involving loudspeaker trucks have been passed on by the Supreme Court. The confusion they produced cautions against too heavy reliance on Kovacs. In Saia v. New York, 334 U.S. 558 (1948), the Court struck down a municipal ordinance prohibiting the operation of sound trucks unless a police permit was obtained. While recognizing the right of municipalities to regulate the use of the streets, the Court found the ordinance unconstitutional as a prior restraint on free speech.

Kovacs v. Cooper, 396 U.S. 77 (1949), a 5-4 decision, was handed down not long thereafter, the majority producing three opinions. The confusion this multiplicity of opinions creates is augmented by the ambiguity of the ordinance itself, since it could be read as banning all sound trucks or only "loud and raucous" ones. Of the majority, Justices Frankfurter and Jackson would have upheld the ordinance as an absolute ban on all sound truck use. The other three Justices in the majority, Justices Reed, Vinson, and Burton, upheld the ordinance because the New Jersey courts had read it as only barring sound trucks emitting "loud and raucous noises." Thus, these three, combined with the four dissenters, felt that not all sound trucks could be banned.

The Court also could not agree as to whether Saia was overruled by Kovacs. Reasoning that there was no problem of prior restraint in the latter, Justices Reed and Burton, and 
It is not possible to extract determinative criteria from these decisions as to when a disturbing practice involving speech can be prohibited. However, Kovacs does at least show that a serious enough disruption can be legislatively proscribed. Both cases deal with what, had they been legally categorized, would be termed public nuisances-disturbances which affect all, or a significant segment, of the public. ${ }^{51}$ It is the legal category of private nuisance, however, looking to the discomforts inflicted on the specific property owner, ${ }^{52}$ which is more properly assimilable to the residential picketing situation. Despite this correlation, no American decisions have spoken in terms of "nuisance." However, in J. Lyons \& Sons v. Wilkins, ${ }^{54}$ an English case, this step was suggested. Master of Rolls Lindley reasoned that a nuisance action was supportable, for "such conduct seriously interferes with the ordinary comfort of human existence and ordinary enjoyment of the house beset . . . ."55

Chief Justice Vinson, distinguished the two decisions. Justices Frankfurter and Jackson based their opinions on their dissents in Saia. Justices Black, Douglas, and Rutledge argued that Kovacs repudiated the earlier loudspeaker case. Perhaps the confusion produced is best commented upon by Mr. Justice Rutledge, dissenting: "How, on such a hashing of different views of the thing forbidden, Kovacs could have known with what he was charged or could have prepared a defense, $I$ am unable to see. How anyone can do either in the future, under this decision, $I$ am equally at loss to say." Id. at 105.

51 Prosser, Torrs 605 (3d ed. 1964): "The term [public nuisance] comprehends a miscellaneous and diversified group of minor criminal offenses, based on some interference with the interests of the community or the comfort or convenience of the general public."

52 In regard to private nuisances, Professor Prosser has written: "The essence of a private nuisance is an interference with the use and enjoyment of land . . . [M]any interferences with personal comfort, . . . which at first glance would appear to be wrongs purely personal to the landholder, are treated as nuisances because they interfere with that right to the undisturbed enjoyment of the premises which is inseparable from ownership of the property." $Y d$. at 611 .

53 Some old labor cases have referred to picketing of businesses as a nuisance. See, e.g., Moore v. Cooks' Union, 39 Cal. App. 538, 179 Pac. 417 (1919); Hughes v. Kansas City Motion Picture Machine Operators, 282 Mo. 304, 221 S.W. 95, cert. denied, 254 U.S. 632 (1920); F. G. Church Shoe Co. v. Turner, 218 Mo. App. 516, 531, 279 S.W. 232, 236 (1926): "When, however, intimidation, threats, and violence are resorted to, the picketing, so conducted, may properly be held to establish a nuisance and is subject to be enjoined."

54 [1899] I Ch. D. 255. See also Reg. v. Donnelly \& Brierly, an unreported Canadian decision cited in Winkler, Picketing of Private Homes: The Anomalous Peaceful Picketing Clause, 2 Oscoode Hall L.J. 437, 447, 450 (1963); Rex v. Elford, 87 Can. Crim. Cas. 372 (1947).

55 [1899] I Ch. D. 255, 267-68 (opinion of Master of Rolls Lindley). Chitty, L.J., also concluded that the activity here was a nuisance. $I d$. at 271 . The court held that the defendants' activity violated a statute forbidding watching and besetting a man's house, save for the purpose of obtaining and communicating information. Conspiracy and Protection of Property Act, 38 \& 39 Vict,, c. 86, § 7 (1875). (By the Trade Disputes Act, 6 Edw. 7, C. $47(1906)$, it was made lawful to "attend at or near a house or place where a person resides" for the purpose of "peacefully obtaining or communicating information" or of "peacefully persuading any person to work or abstain from working." Trade Disputes 
While the Lyons language is well taken, it has been said in regard to private nuisances that "by prevailing view, interference must affect the physical senses of the occupant rather than his state of mind."s6 Admittedly, silent picketers may only affect the sensation of sight, and even this disturbance may be minimal for the public official secluded on the 20th floor of an apartment building. Nevertheless, the residential picketer undeniably induces some sort of mental distress in the homeowner. It is this disorientation of the residential environment, and its consequences upon the official and his family, which brings residential picketing close to, even if not completely within, the ambit of nuisance law.

\section{Privacy}

While past decisions do not present a clear resolution where the homeowner's interest in privacy is weighed against the values of free speech, it is clear that privacy has been considered a significant, and perhaps even determinative, factor. ${ }^{57}$ In Martin v. City of Struthers ${ }^{58}$ the appellant, who had distributed religious literature, was convicted of violating an ordinance prohibiting house-to-house distribution of circulars. In balancing competing interests, the Court concluded that the homeowner's desire for privacy was outweighed by considerations of free speech and the free exercise of religion. While deferent to privacy's importance, the Court felt that the individual householder could dissuade solicitation, whereas use of an ordinance cut off communication to those who would choose to listen. ${ }^{59}$ In the later case of Breard $v$. Alexandria, ${ }^{60}$ however, the Court upheld an ordinance which prohibited house-to-house solicitation. It balanced the householder's "desire for privacy and the publisher's right to distribute publications" 61 by such solicitation, and found the latter interest subordinate.

Martin and Breard are not necessarily inconsistent, although

Act, 6 Edw. 7, c. 47, $\$ 2$ (1906). In 1927 residential picketing was made unlawful. Trade Unions Act, $17 \& 18$ Geo. 5, c. 22 (1927). This act has since been repealed by the Trade Disputes and Trade Union Act, 9 \& 10 Geo. 6, c. 52 (1946).

The court's discussion of nuisance in Lyons has not gone without criticism. See Finkelman, The Law of Picketing in Canada: I, 2 U. of ToRonro L.J. 67, 98-99 (1937). However, the author acknowledges that on its facts Lyons is supportable. Id. at 90.

56 MARTZ, Rights INCIDENT to Possession of LAND $73 \mathrm{n} .2$ (1954).

67 See generally Comment, Constitutional Right of Privacy, 40 N.C.L. REv. 788, 794-99 (1962).

58319 U.S. 141 (1943).

59 But see Chafee, Free SPEech in the UNITEd States 406-07 (1948).

60341 U.S. 622 (1951).

$61 \mathrm{Id}$. at 644 . 
the dissent in the latter subscribed to this view. ${ }^{62}$ In dealing with the problems of free speech, the Court has endorsed a distinction between public appeals involving commercial endeavors and those concerning dissemination of political and religious information. Thus, the distribution on the streets of leaflets propagandizing religion may not be unduly suppressed, but only regulated, while municipal authorities are not similarly constrained when the handbill's message is commercial advertising. ${ }^{63}$

Certainly the Martin decision, even if narrowly read as condemnation of a specific mode of prohibition, detracts from privacy's standing as a determinative factor in considering proscription of residential picketing. However, several distinctions, suggested by the loudspeaker truck case, Kovacs $v$. Cooper, ${ }^{64}$ mitigate its weight. In Kovacs the message being disseminated dealt with a labor dispute, a matter long recognized as being of public concern, ${ }^{65}$ yet the ordinance was upheld. Clearly, then, the method used to convey speech on the streets may justify prohibition even if that speech is non-commercial in character. The speech in Kovacs involved a significant plus factor-the noise of the loudspeakers. The activity in Martin, on the other hand, was less pervasive and persistent-a single ringing of the doorbell is soon terminated, and not likely repeated. In terms of duration of the disturbance, the possibility of its repetition, and the degree of discomfort, residential picketing would seem to approximate the Kovacs situation, rather than that in Martin.

There is another distinction which the Martin opinion suggests. The Court reasoned that the householder could simply reject the religious propagandist by indicating in an appropriate manner a desire not to be disturbed. The same flexibility of approach would not be available to dissuade loudspeaker users. The same is true, of course, of the victim of residential picketers-it is doubtful that he could discourage their efforts by a simple doorstep confrontation.

This reading of Martin and Kovacs, augmented by the solicitude for the homeowner's privacy evidenced in Breard, presses for recognition of privacy as a strong factor militating against residential picketing. ${ }^{66}$

62 Id. at 649-50.

63 See, e.g., Valentine v. Chrestensen, 316, U.S. 52 (1942). See also Murdock v. Pennsylvania, 319 U.S. 105 (1943); Jamison v. Texas, 318 U.S. 413, 416 (1943).

64336 U.S. 77 (1949).

65 See, e.g., Thornhill v. Alabama, 310 U.S. 88 (1941).

66 Even in Thornhill v. Alabama, 310 U.S. 88 (1941), see note 40 supra, which originally assimilated labor picketing to free speech, privacy was acknowledged as a valid competing interest to be considered when picketing is pursued. Id. at 105. See also Carlson v. California, 310 U.S. 106, 113 (1941). 
It is not surprising, therefore, that the importance of the homeowner's privacy has been acknowledged, either explicitly or by implication, in several decisions dealing with labor residential picketing. ${ }^{67} \mathrm{~A}$ recent non-labor residential picketing decision presents one of the strongest statements of this view. In Molofsky $v$. Bundy $y^{88}$ the court enjoined patrolling of a tavern licensee's home by citizens protesting the opening of the tavern in their neighborhood, stating that:

When the right to free speech (which is not synonymous with picketing) is weighed against the right to privacy, the balance favors the privacy of the home. ${ }^{69}$

\section{The Public Man and the Alternative Situs}

While it is clear, then, that the factor of privacy cannot be ignored, it must be recognized that the homeowner of concern here is a public official. By the very nature of his calling, he has consciously exposed himself to public scrutiny. The tort law of privacy, recognizing this, has found that the public figure possesses only a limited right of privacy. ${ }^{70}$ A large number of authorities have in fact maintained that he has no such right. ${ }^{11}$ The law of defamation has similarly noted the

o7 See, e.g., United Electrical Workers v. Baldwin, 67 F. Supp. 235 (D. Conn. 1946); Jacobs v. United Furniture Workers, $16 \mathrm{CCH}$ Lab. Cas. 165,065 (L.A. County Super. Ct. Cal. 1949); State v. Cooper, 205 Minn. 333, 285 N.W. 903 (1939); State v. Perry, 196 Minn. 481, 265 N.W. 302 (1936); State v. Zanker, 179 Minn. 355, 229 N.W. 311 (1930); Evening Times Printing \& Publishing Co. v. American Newspaper Guild, 124 N.J. 71, 199 Atl. 598 (1938); People v. Levner, 30 N.Y.S.2d 487 (Magis. Ct. N.Y.C. 1941).

6834 U.S.L. WeEk 2582 (Balt. Cir. Ct. April 16, 1966). See also New York Times, May 15, 1966, \& 4, p. 6, cols. 1-2.

69 U.S.L. WEEK 2582 (April 16, 1966). While the court's adherence to protection of the homeowner's privacy is, it is suggested here, admirable, the opinion is somewhat flawed. Reliance is placed on Griswold v. Connecticut, 381 U.S. 479 (1965), in which Mr. Justice Douglas invoked a constitutional right of marital privacy to strike down a Connecticut birth control law. The discovery of a limited form of privacy to render state action unconstitutional cannot determine the ability of a state court to enjoin private action disruptive of a dissimilar form of privacy. See also Zeeman v. Amalgamated Retail \& Dept. Store Employees Union Local 44(D), 25 L.R.R.M. 2343, 17 CGH Lab. Cas. If 65,572 at 76,928 (L.A. County Super. Ct. Cal. 1950), and 26 L.R.R.M. 2422 (1950), where the same court reversed itself. It had first denied an injunction restraining residential picketing, and in doing so, rejected an argument based on invasion of right of privacy. (Within the context of California law, however, it did not have so to reason. See 38 Geo. L.J. 687 (1950).) In the second decision, some months later, it reversed and granted the injunction without preserving its rationale as to its disposition of the privacy argument.

70 See, e.g., Sidis v. F-R Publishing Corp., 113 F.2d 806 (2d Cir. 1940). See also Prosser, TorTs 845 (3d ed. 1964). This is apparently the majority view. See Spiegel, Public Celebrity v. Scandal Magazine-The Celebrity's Right to Privacy, 30 So. CAL. L. REv. 280, 297 (1957).

71 See Spiegel, supra note 70, at 296. 
public nature of a well-known figure's life. ${ }^{72}$ Thus, the public figure has "to be able to take it," "3 and not "go about with his feelings on his sleeve." 74 The Supreme Court has gone so far as to adopt the rule, in New York Times Co. v. Sullivan, ${ }^{75}$ that an official cannot recover damages for a defamatory falsehood unless the statement was uttered with "actual malice."

Yet the interests of the public official are not entirely subordinated to those of the public. Both privacy and libel law have endorsed a distinction between the public official as a public man and as a private citizen. Thus, the Sullivan rule is limited to statements relating to "official conduct"; ${ }^{76}$ and the tort law of privacy disavows investigation "into those matters and transactions of private life which are wholly foreign, and can throw no light whatever upon the question as to [the official's] competency for the office, or the propriety of bestowing it upon him." 77 Acceptance of the public figure as having a diluted right of privacy does not, therefore, dispositively weight the argument in favor of residential picketing; it would seem that his home is so dissociated from his governmental functions as to stand apart from the public aspect of his life. ${ }^{78}$

72 See, e.g., New York Times Co. v. Sullivan, 376 U.S. 254 (1964); Noel, Defamation of Public Officers and Candidates, 49 CoLUM. L. Rev. 875 (1949). See also Themo v. New England Newspaper Publishing Co., 306 Mass. 54, 57, 27 N.E.2d 753, 755 (1940): "The fundamental difference between a right to privacy and a right to freedom from defamation is that the former directly concerns one's own peace of mind, while the latter concerns primarily one's reputation ...." see generally Wade, Defamation and the Right of Privacy, 15 VAND. L. Rev. 1093 (1962). Of course, federal law provides for an extensive use of the official's privilege to commit defamation and be immune from suit. (State law is not so clear.) Barr v. Matteo, 360 U.S. 564, 575 (1959); cf. Gregoire v. Biddle, 177 F.2d 579 (2d Cir. 1949) (L. Hand, J.). See also Kurat v. County of Nassau, 264 N.Y.S.2d 126 (Sup. Ct. 1965). The purpose in this, however, is not to salve the official's sensitivities, but to insure that he is not harassed by suits and need not therefore fear to act. See generally Becht, The Absolute Privilege of the Executive in Defamation, 15 VAND. L. REv. 1127 (1962), wherein the author urges that there be only a qualified privilege.

73 People v. Drucker, 167 Misc. 557, 4 N.Y.S.2d 360, 362 (Kings County Ct. 1938).

74 Sweeney v. Caller-Times Publishing Co., 41 F. Supp. 163, 168 (S.D. Tex. 1941).

75376 U.S. $254,279-80$ (1964).

$76 \mathrm{Id}$. at 279.

77 Pavesich v. New England Life Ins. Co., 122 Ga. 190, 199-200, 50 S.E. 68, 72 (1905). See also Griffin v. Opinion Publishing Co., 114 Mont. 502, 138 P.2d 580 (1943); Warren \& Brandeis, The Right to Privacy, 4 Harv. L. REv. 193, 216 (1891).

78 Cf. Prosser, Torts 848 (3d ed. 1964). If the official's office were in his home, and there were thus no other suitable forum wherein he could be directly confronted, picketing of the home would perhaps have to be allowed. See Senn v. Tile Layers Union, 301 U.S. 468 (1937). Contra, State v. Cooper, 205 Minn. 333, 285 N.W. 903 (1939). A publicly supported residence would also be arguably more amenable to residential picketing. Such residences would be Gracie Mansion, which has been picketed, see Sunday New York 
That area which does have direct relevance to the official's public character is the office, at which the action causing the grievance was taken and which is the locus of his authority. ${ }^{79}$ The public parks, also, while not as related to the grievance, are open to the protestors. ${ }^{80}$ These sites afford suitable areas for remonstrance. Subscribing to similar reasoning, some of the labor residential picketing cases have endorsed the idea of limiting picketing to the site associated with the complaint. Thus, in Evening Times Printing \& Publishing Co. v. American Newspaper Guild ${ }^{81}$ the court affirmed the lower court's restraining orders: "The lawful place for defendants' picketing operations is at the site of the employment ... where the working conditions to which the strikers object or which they seek to improve do or will maintain . . . ."82

Despite the logic of confining disputes to the source of their origin, rather than only peripherally associated sites, it is clear that an appropriate use of the streets cannot be abridged merely by arguing that other sites are available. ${ }^{83}$ However, since the disruptive consequences of residential picketing call into question its appropriateness, it is worthwhile to note the presence of other areas of expression, since these appreciably lessen the danger of prohibition which totally stifles communication. Of course, justifying proscription of residential picketing by invoking the availability of alternative sites is premised partly on the assumption that the picketing of public buildings is possible. Such exercise was strongly sanctioned in Edwards $v$. South Carolina. ${ }^{84}$ While legislative proscription of such activity has occurred, as evidenced in

Times, Oct. 11, 1964, $\$ 1$, p. 80 , cols. 2-3, and the White House, see Scott v. District of Columbia, 184 A.2d 849 (Munic. Ct. D.C. 1962).

79 Cf. People v. Levner, 30 N.Y.S.2d 487, 493 (Magis. Ct. N.X.C. 1941). Picketing at the office site has been before the courts in Edwards v. South Carolina, 372 U.S. 229 (1963); Scott v. District of Columbia, 184 A.2d 849 (Munic. Ct. D.C. 1962) (judicial note taken of picketing of the White House); Matter of Brinn, 305 N.Y. 887, 114 N.E.2d 430 (1953); People v. Carcel, 3 N.Y.2d 327, 144 N.E.2d 81, 165 N.Y.S.2d 113 (picketing at the United Nations building in New York City). See also Chicago Tribune, June 16, 1965, \& 1B, p. 5 , cols. 3-4 (picketing of Justice Department building in Washington, D.C.).

80 Hague v. CrO, 307 U.S. 496, 515 (1939).

81124 N.J. Eq. 71, 199 Atl. 598 (1938).

82 Id. at 83, 199 Atl, at 605 . See also Jacobs v. United Furniture Workers, $16 \mathrm{CCH}$ Lab. Cas. If 65,065 at 75,372 (L.A. County Super. Ct. Cal. 1949); cf. State v. Perry, 196 Minn. 481, 482, 265 N.W. 302 (1936); Hebrew Home and Hospital for Chronic Sick, Inc. v. Davis, 38 Misc. 2d 173, 177-78, 235 N.Y.S.2d 318, 324 (Sup. Ct. 1962); Springfield, Bayside Corp. v. Hochman, 44 Misc. 2d 882, 255 N.Y.S.2d 140 (Sup. Ct. 1964); People v. Kopezak, 153 Misc. 187, 274 N.Y. Supp. 629 (Sup. Ct.), aff'd, 266 N.Y. 565, 195 N.E. 202 (1934).

83 Schneider v. State, 308 U.S. 147, 163 (1939).

84372 U.S. 229 (1963). 
the second Cox decision and in Frend $v$. United States, ${ }^{85}$ these instances are manifestations of specific needs rather than examples of a general policy. ${ }^{86}$

The usual type of residential picketing, which it is suggested should be properly removed to the public building, will involve an official who can be, and should be, responsive to the public will. At this juncture, Edwards assumes its proper relevancy. Of course, even in Edwards the Court acknowledged the feasibility of a statute prohibiting demonstrations before the state legislatures. ${ }^{87}$ However, while the dangers of steadily diminishing sites for demonstration may be discomfortingly real, ${ }^{88}$ it would be anamalous to argue that because the courthouse or

85100 F.2d 691, cert. denied, 306 U.S. 640 (1938).

86 Cox is explicable in terms of the building-a courthouse-which was withdrawn from the possible sites for demonstrations, and the desire to maintain the impartiality of the judiciary. In Frend, a joint resolution of Congress prohibiting demonstrations within 500 feet of foreign embassies was upheld and the conviction of the appellants sustained. The court relied in part on the peculiar requirements of relations with other nations in reaching this conclusion. Of course, other quasi-public buildings have been removed from the potential sites for picketing. See, e.g., Abyssinian Baptist Church v. African Nationalist Movement, 71 N.Y.S.2d 93 (Sup. Ct. 1947).

87372 U.S. at 236.

88 In Adderley v. Florida, 35 U.S.L. WEEK 4013 (Nov. 14, 1966) a sharply divided 5-4 Court sustained the malicious trespass convictions of 32 demonstrators who had gathered on the driveway and lawn area of a county jail. Unlike the second Cox decision, 379 U.S. 559 (1965), and Frend v. United States, 100 F.2d 691, cert. denied, 306 U.S. 640 (1938), see notes 85-86 supra and accompanying text, there was no legislative designation of jails as sites unsuitable for protest. Mr. Justice Black's opinion is therefore significant for its suggestion of a criterion to determine such areas, when these have not been otherwise defined: "In Edwards, the demonstrators went to the South Carolina State Capitol grounds to protest. In this case they went to the jail. Traditionally, state capitol grounds are open to the public. Jails, built for security purposes, are not." 35 U.S.L. WEEK at 4014. (Emphasis added.) Traditional usages of public areas, then, will serve as a guideline for determining the appropriateness of potential demonstration sites.

But characterizing the activity here as a "petition for redress of grievances," 35 U.S.L. WEEK at 4017, Mr. Justice Douglas argued, in a dissent in which the Chief Justice and Justices Brennan and Fortas joined: "The jailhouse, like an executive mansion, a legislative chamber, a courthouse, or the statehouse itself . . . is one of the seats of government whether it be the Tower of London, the Bastille, or a small county jail. And when it houses political prisoners or those whom many think are unjustly held, it is an obvious center for protest." 35 U.S.L. WEEK at 4016.

Two other recent opinions, both of little help, have been handed down by the Supreme Court in regard to the employment of public buildings for peaceful demonstrations. In Cameron v. Johnson, 381 U.S. 741 (1965), the petitioners were convicted under a Mississippi statute prohibiting picketing or mass demonstrations "in such manner as to obstruct or interfere with free ingress or egress to or from any public premises ... or so as to obstruct or interfere with free use of public streets, sidewalks or other public ways adjacent thereto." MIss. Cone ANN. § 2818.5 (Supp. 1964). In a 5-4 per curiam opinion, the Court vacated the district court's decision, which had denied the appellants' attempt to enjoin enforcement of the law, and remanded. It did not approach the question of whether demonstrations before public buildings are constitu- 
the legislature may not be picketed, the home of the judge or legislator is a necessary situs. If the aim is to protect the official, and to insulate him from untoward pressures, the first step in implementing this goal is to guard his home life.

\section{"The Freedom Not to Listen"-The Captive Audience}

The terms "nuisance" and "privacy" evoke numerous, not easily articulated connotations. Even as terms of legal art, they are ambiguous. When applied to residential picketing, they involve a problem which has gained increasing consideration. ${ }^{89}$ The official and his family are a captive audience, ${ }^{90}$ a circumstance detailed by the Court in Kovacs $v$. Cooper, ${ }^{91}$ which concerned regulation of loudspeaker trucks:

The unwilling listener is not like the passerby who may be offered a pamphlet in the street but cannot be made to take it. In his home or on the street he is practically helpless to escape the interference with his privacy by loudspeakers $^{22}$...

Public Utilities Commission v. Pollak ${ }^{93}$ presents the Court's most notable confrontation with the captive audience. The Commission had allowed a privately owned public utility corporation. to install radio receivers in the buses it operated. Consequently, passengers were subjected to programming of which $90 \%$ was music and $10 \%$ was commercials and announcements. It was contended on behalf of the

tionally protected. (Actually, this question was not raised, since the appellants' contentions were based on the vagueness of the statute, and on the inequality of its application.)

Brown v. Louisiana, 86 S. Ct. 719 (1966), also is of no aid in discerning the availability of areas outside public buildings for peaceful demonstrations. The petitioner Negroes, who had gathered in a public library, were convicted of violating a Louisiana statute making it a criminal offense to congregate in a public building with intent to provoke, or under circumstances that might occasion, a breach of the peace, and to refuse to move on when so ordered. On certiorari, the Court reversed, four Justices, in 2 opinions, finding no evidence to warrant the conviction, and Mr. Justice Brennan finding the statute overly broad. However, since the activity in question occurred in a building, the case is clearly distinguishable.

89 See, e.g., Kalven, The Negro and the First Amendment 147-60; Konvitz, Fundaaiental Liberties of a Free People 119-27 (1957).

90 This consequence is specifically acknowledged in Cox v. Louisiana, 379 U.S. 536, 578 (1965) (Black, J., concurring); cf. Kunz v. New York, 340 U.S. 290, 307 (1951) (Jackson, J., dissenting).

91336 U.S. 77 (1949).

92 Id. at 86-87 It is suggested here that "listener" should not be read literally so as to deny the assertion that silent picketers do not make the homeowner a captive audience. While the picketers may be silent, their presence constitutes a pressure which impinges on the senses.

93343 U.S. 451 (1952). 
passengers that the Commission's order violated the Fifth Amendment by invading privacy. The Court rejected this contention, but in doing so it drew a distinction between the home and a bus:

This position wrongly assumes that the Fifth Amendment secures to each passenger on a public vehicle ... a right of privacy substantially equal to the privacy to which he is entitled in his own home. . . .94

Although the Court did not pass on the rights of the captive homeowner, it did thus acknowledge the distinction between his plight and that of an "individual in a public vehicle or public place."'э5 This distinction is a reasonable one, for while a bus is invested with a public character, the home is the retreat of the individual. Moreover, the passenger knowingly accepts the discomforts to which he will be exposed..$^{96}$ This is not the case with residential picketing, where the only recourse presented the homeowner and his family is to leave their home. Such an eventuality negates the traditional notions of security and privacy associated with the home in our society. ${ }^{97}$

Admittedly, the problem of the captive audience arises whenever picketing occurs. Because the situs of concern here is the home, however, the problem is particularly acute. While the public official's obligations to his constituents arguably create a duty on his part to listen to their grievances, ${ }^{98}$ the same burden cannot be said to be incumbent upon his family.

\section{The Case for the Picketers}

It remains to be determined whether the advantages which the residential picketers derive are persuasive enough to outweigh the

94 Id. at 464 .

$85 \mathrm{Id}$. at 465.

96 But see Black, He Cannot Choose But Hear: The Plight of the Captive Auditor, 53 CoLum. L. REv. 960, 964-65 (1953). Interestingly, a recent novel about a fictional Supreme Court Justice recreates the facts of the Pollak case. In the novel, the majority finds a violation of the Constitution. In preparing the majority opinion, the protagonist reasons: "The relationship between the bus company and the passengers isn't voluntary. They're forced to ride-and therefore forced to listen. Ordinary people can't afford to take taxis to work every day, or keep a car, or move to another neighborhood just to avoid something they find annoying." WoOLFOLK, OPINION OF THE COURT 119 (1966).

97 In commenting on the special nature of the home, it has been written: "Freedom of the home is as important as freedom of speech." ChafEe, Free SPEech IN THE UNITED Stares 407 (1948 ed.). Illustrative of the special notions of security associated with one's domicile is People v. Tomlins, 213 N.Y. 240, 243, 107 N.E. 496, 497 (1914), explicating that there is no duty in criminal law to retreat when the householder is attacked in his own home.

98 See, e.g., Brown, The Right to Petition: Political or Legal Freedom?, 8 U.C.L.A.L. REv. 729, 732-33 (1961). 
interests of the homeowner-public official. As has been noted, the picketers' claim to the streets is a powerful one, predicated not only on the fact that they are engaged in activity involving the expression of political ideas, but also on the nature of the streets as a traditional public forum. ${ }^{99}$

The streets and sidewalks afford the picketers the benefit of minimal costs. This consideration cannot be dismissed; it is often those who are most aggrieved, and whose grievances most deserve publication, who are least able to finance the expression of their complaints. ${ }^{100}$ Economics alone, however, is small justification for residential picketing. ${ }^{101}$ Since other sites remain open, there can be little added monetary burden flowing from their use. Moreover, the mundane problems of logistics probably make central assembly areas more accessible, and hence more economical, than comparatively isolated neighborhoods.

More significant are the dual factors of publication and publicity:

[T] here are not so many places and times available to the ordinary speaker, and the assurance of an interested audience is not always easy. For even if listeners must be free not to listen, the public freedom of speech requires that all speakers have a chance to reach them.102

Because residential picketing is an unusual mode of remonstrance, it may well earn the picketers a larger audience through the news media than they could otherwise obtain. ${ }^{103}$ Yet access to audiences cannot justify what would otherwise be an unwarranted activity. Of course, there may be a curious system of inverse progressions operating, whereby as the difficulty of reaching one's audience increases, the permissible bars to communication decrease. ${ }^{104}$ Thus, the ease of other means of publication served as a justification for sustaining the ordinance in the

99 Hague v. CIO, 307 U.S. 496,515 (1939).

100 Cf. Adderly v. Florida, 35 U.S.L. WEEK 4013, 4017 (Nov. 14, 1966) (Douglas, J., dissenting); Martin v. City of Struthers, 319 U.S. 141, 146 (1943).

101 Cf. Kovacs v. Cooper, 336 U.S. 77, 88-89 (1949) (quoted in text accompanying note 49 supra).

102 Metrlejohn, Freedom ANd the Public 112 (1965).

103 In a speech before the Radio Television News Directors Ass'n, on September 28, 1966, Mayor Daley of Chicago criticized news media coverage of civil rights demonstrations, condemning their preoccupation with conflict. He cited the assignment of thirtyseven newsmen to report the patrolling of his home by eighteen pickets as an example of news coverage disproportionate to the event. Chicago Sun-Times, Sept. 29, 1966, p. 8, reaction by Mayor Daley's neighbors warranted television coverage. Chicago Sun-Times, Sept. 29, 1966, p. 9, cols. 1-3. See Chicago Sun-Times, Aug. 17, 1963, p. 14, cols. 1-4, at col. 4; cf. Kamin, Picketing 214-15.

cols. 1-6. In justification, a news media representative reasoned that the possibility of 104 See, e.g., Bakery Drivers v. Wohl, 315 U.S. 769, 775 (1942). 
loudspeaker case, ${ }^{105}$ while the relative penury of religious propagandists served as a rationale for striking down the Martin ordinance, ${ }^{108}$ which barred house-to-house solicitation.

Whether this be the case or not, it would seem clear that the constant public examination of the public official's life and of his actions provides ready access to news channels. Picketing at a site other than his home would therefore still find an audience in the news media. Moreover, in terms of the public's personal confrontation with the picketing, the official's office will almost certainly be situated in a location more frequented by the public than is his home. Thus, the loss in publicity which would follow from precluding the residential situs as a forum is probably appreciably offset by these factors.

Another consideration which weighs in favor of residential picketing is its persuasive impact on the public official. The singularity of the activity, combined with the physical presence of aggrieved citizens and with the mentally distressing consequences of this presence, may serve to impress and even persuade the official more than would newspaper editorials or picketing of his office. Similar sentiments were voiced by the court in United Electrical Workers $v$. Baldwin, ${ }^{107}$ which involved labor residential picketing:

Picketing of this type brings home the fact that a man may leave his tools at his work, but not his conscience or his relations with his fellow man. ${ }^{108}$

Thus, also, the public official's recognition of his responsibility to his constituents should not cease once he enters the confines of his home; residential picketing emphasizes this fact to him. Nevertheless, the news media and other opinion-creating bodies do strongly influence the official. The continual and contrary pressures exerted on him are significant, even without the added factor of picketers outside his home. Again, even tort law, which only affords the public figure limited protection, does not vouchsafe unwarranted invasion into his private life, even though added publicity and persuasiveness might be gained thereby.

\section{Summary}

The arguments in favor of residential picketing largely converge on the "sales" aspect of speech. Their thrust concerns entrance into the

105 Kovacs v. Cooper, 336 U.S. 77, 88-89 (1949) (quoted in text accompanying note 49 supra).

106 Martin v. City of Struthers, 319 U.S. 141, 146 (1943).

10767 F. Supp. 235 (D. Conn. 1946).

108 Id. at 242. 
proverbial "marketplace of ideas." Undeniably, the advantages of publicity and impact are to a degree unique, and are dependent on the residence as the situs of picketing. These benefits can be approximated by picketing, as well as other forms of remonstrance, elserwhere. On the other hand, the "costs" incurred by the homeowner-public official are singular. $\mathrm{He}$ and his family are made a captive audience; the privacy and enjoyment of their home are disturbed. Unlike the protestors, the homeowner and his family do not have a choice of alternatives-they cannot go to another home.

\section{The Form of Prohibition}

If the interests of the homeowner-public official are deemed suffciently compelling to warrant the regulation or proscription of residential picketing, as is suggested here, the question arises as to how the law can effect this end. Three approaches are available: (1) application of common law offenses; (2) use of a licensing system; or (3) enactment of a statute specifically prohibiting the activity.

\section{The Common Law-Nuisance and Privacy}

While both nuisance and invasion of privacy are potential legal categories in which to place residential picketing, they possess serious drawbacks both in terms of applicability and application. It has been said in regard to nuisance that "probably no single tort embraces a wider variety of wrongs." 109 While common principles are applied to both public and private nuisances, ${ }^{110}$ there is one distinction between the two which is significant in dealing with residential picketing. This is the problem of the proper plaintiff. A municipality cannot seek redress for a private nuisance, nor can an individual seek remedy for a public nuisance unless he suffers some special injury. ${ }^{111}$ Undoubtedly there will be occasions when the disruptive consequences of residential picketing will be so generalized as to allow the public authorities to act. However, a small group of silent marchers may have a deleterious effect solely on their specific target. Therefore, to accept the nuisance category as sufficient always to enable municipal action is not feasible. Of course, since almost every instance of picketing will particularly affect the homeowner, even if its consequences are at the same time of sufficient degree to constitute a public nuisance, he would probably always be a proper plaintiff. Possibly he could gain relief, for while it

109 Chafee, Cases on Equity 796 (4th ed. 1958).

110 LEWIS \& SpEELling, The LAW OF INJunctions § 281, at 555 (1926).

111 See, e.g., Whitmore v. Brown, 102 Me. 47, 57, 65 Atl. 516, 520 (1906); Elves v. King County, 49 Wash. 2d 201, 299 P.2d 206 (1956). 
is true that nuisance law looks mainly to direct sensory disturbances, on occasion purely mental distress independent of direct sensory impact on the property owner has supported a nuisance suit.112

Whether the municipal authorities, or the individual homeowner, or both, could take legal action, there would be difficulties with the use of injunctive relief, as well as with a suit for damages. ${ }^{113}$ Generally, an injunction covers both the defendant to the suit and those who act as his agents, servants, associates, or confederates. ${ }^{114}$ However, "no court can ... lawfully enjoin the world at large, no matter how broadly it words its decree."115 Thus, in a situation where a completely unorganized group of protestors motivated by a common grievance pickets an official's residence, an injunction might not effectively operate. Moreover, accession by the official to one group might arouse another, which would not be barred by the already issued injunction. Perhaps more relevant in terms of political realities is the possibility that the official would not be politically positioned to bring suit, lest such action alienate theretofore neutral citizens on whom he is dependent for support.

The major objection to defining residential picketing in terms of nuisance law, however, is a more subjective one. This is a constitutionally colored activity; its practice is not so blatantly improper as to evoke bland denunciation. The law of private nuisance is simply not

112 A nuisance may be a mortuary which has a depressing effect, Kundinger v. Bagnasco, 298 Mich. 15, 298 N.W. 386 (1941), a tuberculosis hospital which arouses a fear of contagion, Everett v. Paschall, 61 Wash. 47, 111 Pač. 879 (1910), a bawdy house which disturbs peace of mind, Grawford v. Tyrell, 128 N.Y. 341,28 N.E. 514 (1891). See generally 35 ORE. L. REV. 216 (1956).

113 The injured party may recover not only damages for his property losses, but also for personal inconvenience and discomfort. Thus in Bankston v. Farmers Cooperative Gin, 116 So. 2d 91 (La. Ct. App. 1959), damages were allowed for inconvenience, mental anguish and suffering resulting from deposit of gin waste, even though damage to property was not proved. In Hall v. Stokely-Van Camp, Inc., 259 Minn. 101, 106 N.W.2d 8 (1960), the jury was given discretion in setting damages for personal discomfort and annoyance, once it was found that odors from the defendant company's factory were offensive. In regard to the problems the allowance of such damages raises, see text accompanying notes $123-24$ infra.

Nuisance law also affords the self-help remedy of abatement. However, this would probably not be feasible when residential picketing occurs. The only way the homeowner could abate the picketing would be physically to remove the picketers. This would almost certainly lead to a breach of the peace, at the very least, and one abating a nuisance is not privileged to create such a disturbance. Schleif v. State, 131 Neb. 875,270 N.W. 510 (1936).

114 See generally Annot., 15 A.L.R. 386 (1921).

115 Alemite Mfg. Corp. v. Staff, 42 F.2d 832 (2d Cir. 1930). See generally Developments in the Law-Injunctions, 78 HARv. L. REv. 994, 1028-31 (1965). 
suited to preclude its exercise. The word "nuisance" itself has been described as a "sort of legal garbage can,"116 and the same commentator notes that "there has been a deplorable tendency ... to call something a 'nuisance' and let it go at that."117 Prohibition of residential picketing merits considered legislative judgment, which may be forthcoming when an ordinance or statute is passed declaring an activity a public nuisance, but which is not present in a civil action seeking redress for a private nuisance.

While the tort law of privacy possibly affords a somewhat more fruitful area of development, it too is an imperfect mode of redress. This law has developed in response to mentally offensive publications in the mass communications media. ${ }^{118}$ Dean Prosser has suggested, however, that there are actually four types of invasion of privacy, including "intrusion upon the plaintiff's seclusion or solitude, or into his private affairs." $119 \mathrm{He}$ also indicates that intrusions need not be physical to be actionable as invasions of privacy. ${ }^{120}$ In light of this view, his following statement is particularly apposite:

116 Prosser, Nuisance Without Fault, 20 Texas L. REv. 399, 410 (1942).

117 Ibid.; cf. FRANKFurter \& GREene, The Labor INJUNction 20 (1930): “'Nuisance' is not a very happy or adequate concept from which to evolve law for regulating the clash of conduct in modern industrial relations."

118 The development of this area of the law is traced back to a famous law review article: Warren \& Brandeis, The Right to Privacy, 4 HARv. L. Rev. 193 (1890). The authors maintained that because of the invasions of an enterprising and often intrusive press, there was a need for the law to recognize and protect privacy. Since then, the tort of invasion of privacy has gained wide currency. See generally Nizer, The Right of Privacy, 39 Mich. L. Rev. 526 (1941); Prosser, Privacy, 48 CaL. L. Rev. 383 (1960).

The right of privacy has been referred to as "the right to live one's life in seclusion, without being subjected to unwarranted and undesired publicity. In short, it is the right to be let alone." Kerby v. Hal Roach Studios, Inc., 53 Cal. App. 2d 207, 210, 127 P.2d 577,579 (1942). An invasion of privacy is an "injury to the feelings of the plaintiff, the mental anguish and distress caused ...."Bernstein v. National Broadcasting Co., 129 F. Supp. 817, 825 (D.D.C. 1955), aff'd, 232 F.2d 369 (D.C. Cir. 1956). The most usual form in which this injury occurs is by publication of a picture of or a story about the plaintiff.

of course, the invasion of one's privacy by another individual must be distinguished from governmental intrusion. Thus, the privacy of which the Court speaks in Mapp v. Ohio, 367 U.S. 648, 656 (1961), and in Griswold v. Connecticut, 381 U.S. 479 (1965), is distinct from that privacy which is protected by tort law. The observation of the court in Spahn v. Julian Messner, Inc., 43 Misc. 2d 219, 250 N.Y.S.2d 529, 534 (Sup. C.t. 1964), is apposite, however: "[I]t cannot be doubted that the stature and scope of the private law right have been greatly enhanced by the recent development of its constitutional counterpart."

118 Prosser, Privacy, 48 CAL. L. Rev. 383, 389 (1960).

120 Prosser, TORTs 833 ( $3 \mathrm{~d}$ ed. 1964). The difficulty with Dean Prosser's position, however, arises out of the decisions he cites to support his statement that intrusions need not be physical. Id. at 838, n.56-65. Most of them do not rely on the theory of invasion of privacy, and thus are cognizable as privacy cases only within the generalized meaning of 
It is clear ... that the public figure loses his right of privacy only to a limited extent. ... The famous motion picture actress who "vants to be alone" unquestionably has as much right as anyone else to be free from intrusion into her home. ....121

If intrusions need not be physical, it might appear that residential picketing could be an actionable invasion of privacy, as was apparently held in Molofsky v. Bundy, where the court enjoined the picketers. ${ }^{122}$

If the tort law of privacy were applied to residential picketing, however, the same problems would arise in regard to the injunctive remedy as exist with nuisance law. If damages were sought from an unorganized group of picketers the difficulty of reaching them all in one suit might require a multiplicity of actions as different picketers parade. Invasion of privacy, moreover, is a dignitary tort allowing damages for mental suffering. Such damages might be nominal, thereby doing little to deter future demonstrations. A jury might well feel that a public official, whose right to privacy is diminished already, has "asked" for what has happened, both by virtue of his seeking the public eye and because it was his actions which engendered the grievance. ${ }^{123}$ On the other hand, there is the possibility of severe damage awards if the picketers are advocating an unpopular position:

Juries hostile to the aims of an organization in the educational or political field, unless carefully confined by meticulous instructions and judicial supervision, can deliver crushing verdicts that may stifle organized dissent from the views and policies accepted by the majority. ${ }^{124}$

Lastly, there is again the possibility that, because the official is dependent on public support, it will not be politically feasible for him to bring suit.

the term "privacy," rather than within the context of the tort law of privacy. Furthermore, most of the intrusions which these decisions present are indeed physical to some extent, involving actions such as entrance into the home, Walker v. Whittle, $83 \mathrm{Ga}$. App. 445, 64 S.E.2d 87 (1951), or wiretapping, Rhodes v. Graham, 238 Ky. 225, 37 S.W.2d 46 (1931).

121 Prosser, TORTS 848 (3d ed. 1964).

12234 U.S.L. WEEK 2582 (U.S. April 16, 1966).

123 Compare Noel, Defamation of Public Officers and Candidates, 49 CoLum. L. Rev. 875,876 (1949).

124 NAACP v. Overstreet, 384 U.S. 118, 123 (1966) (Douglas, J., dissenting). On damages for invasion of privacy, see generally Note, Recent Developments in the Right of Privacy, 15 U. ChI. L. REv. 926, 932-36 (1948). 


\section{The Minor Criminal Offense ${ }^{125}$}

Since a disorderly conduct ordinance or the common law breach of the peace sanction must cover many types of conduct, each speaks in general language which could easily be interpreted to apply to residential picketing. ${ }^{126}$ It is this looseness of language, and the correlative potential for abuses, which suggest that such an interpretation would be improper and perhaps unconstitutional.

People v. Levner ${ }^{127}$ and Flores v. City and County of Denver ${ }^{128}$ illustrate the ambiguity inherent in these minor criminal offenses. The two cases present quite similar conduct. ${ }^{129}$ In sustaining a conviction of disorderly conduct, the Levner court looked to the large number of people and the consequent potential for danger, and thereby succeeded in dismissing the appellants' constitutional arguments. ${ }^{130}$ Yet the court was careful to avoid equating all residential picketing with this offense; confining its concern to the specific facts, it was not "prepared to state that picketing a home is, in and of itself, disorderly conduct."131 The Flores court, however, clearly perceived broader implications. In reversing the picketers' conviction for disturbing the peace, it not only found insufficient disturbance to warrant the arrest, ${ }^{132}$ but also regarded "the noise involved as incidental to a legiti-

125 While breach of the peace, disorderly conduct, and disturbing the peace are technically distinct offenses, they will be treated interchangeably. These distinctions are not critical, since they all exhibit the same flaws of concern here-vagueness and the correlative potential for abuses.

126 Many other varieties of conduct have been brought within the ambit of these offenses. See Burdick, LAw of Crime $\S$ 715-19 (1946); McQuilin, Municipal CorporaTIONS § 24.101 (3d ed. 1949).

12730 N.Y.S.2d 487 (Magis. Ct. N.Y.C. 1941).

128122 Colo. 71, 220 P.2d 373 (1950).

129 In Levner some 250 persons gathered opposite the apartment of the mayor of New York City to protest the elimination and curtailment of various work projects. Disregarding a warning from the police, the appellants crossed the street to picket; they were subsequently arrested. In Flores about 60 people, including the appellants, assembled in front of the Governor's home, milling around on the sidewalk and lawn, chanting epithets and carrying placards.

13030 N.Y.S.2d at 493: "Hundreds of pickets outside of a man's residence transcends dissemination of information."

131 Ibid.

132 The court reasoned that the ordinance, if read narrowly, could not be invoked because it was necessary that the peace of others actually be disturbed, and there was no evidence of this. Even if the ordinance were read broadly, there still was no violation because the conduct did not constitute a danger to the peace of the community: "There was no evidence of violence, or of likelihood or threat of violence, or of consternation or alarm." 122 Colo. 71, 77, 220 P.2d 378, 376 (1950). 
mate right, ... to appeal to those in authority for redress of grievance by remonstrance ...."133

Although disparate determinations by two different appellate courts are not unusual, the ambiguity illustrated is disturbing. The loose language of ordinances such as those dealt with in these cases opens the way for both broad initial discretion as to whether an arrest should be effected, and a wide range in which judicial discretion can operate. For the basic logistical problem of how residential picketing is to be effectively prohibited, such ambiguity adds difficulties. In terms of constitutional doctrine, such vague statutes and ordinances are viewed with misgivings, as evidenced by the Court's condemnation of the breach of the peace offense in Edwards $v$. South Carolina ${ }^{134}$ and the disturbing the peace statute in the first Cox decision. ${ }^{135}$

Two Minnesota decisions concerning labor residential picketing illustrate another potential misuse of minor criminal sanctions whereby significant policy judgments are unwarrantedly obscured. In State $v$. Zanker ${ }^{138}$ the Court affirmed the conviction of picketers who had patrolled the home of a non-striking co-employee. About twenty people gathered, and "there seems to have been quite a bit of excitement."137 In State v. Perry ${ }^{138}$ the union members carried epithet-inscribed banners. Again spectators gathered, and in this case the wife of the foreman being picketed turned a hose on the marchers. Affirming a conviction for disorderly conduct, the court found that the carrying of the banners caused a breach of the peace.

Both Zanker and Perry may be read as involving not altogether peaceful picketing. As such the two decisions are unexceptionable, since disorder or violence on the part of any picketers would justify police action, ${ }^{139}$ or, in the case of labor picketing, an injunction. ${ }^{140}$ Trouble-

133 Id. at 77,220 P.2d at 376.

134372 U.S. 229, 236-37 (1963).

135 Cox v. Louisiana, 379 U.S. 536, 552 (1965).

136179 Minn. 355, 229 N.W. 311 (1930).

$137 \mathrm{Id}$. at $356,229 \mathrm{~N} . \mathrm{W}$. at 311 .

138196 Minn. 481, 265 N.W. 302 (1936).

139 See, e.g., Garner v. Teamsters Union, 346 U.S. 485, 488 (1953); Miller v. Gallagher, 176 Misc. 647, 28 N.Y.S.2d 606, 610 (Sup. Ct. 1941).

140 See, e.g., Milk Wagon Drivers Union v. Meadowmoor Dairies, 312 U.S. 287 (1941); Ladies' Garment Workers v. Sherry Mfg. Co., 115 So. $2 d 27$ (Fla. Dist. Ct. App. 1959); Remington Rand, Inc. v. Gaul, 13 CGH Lab. Cas. 63987 (N.Y. Sup. Ct. 1947). Tort damages may also be recoverable for injuries suffered due to violent picketing. See, e.g., United Constr. Workers v. Laburnum Constr. Corp., 347 U.S. 656 (1954).

For cases involving labor residential picketing where violence supported an injunction, see International Ticket Co. v. Wendrich, 123 N.J. Eq. 172, 196 Atl. 474 (1938); Miller v. Gallagher, 28 N.Y.S.2d 606 (Sup. Ct. 1941); Busch Jewelry Co. v. United Retail Employees Union, 281 N.Y. 150, 22 N.E.2d 320 (1939); Remington Rand, Inc., v. Crofoot, 289 N.Y. 
some, however, is the court's reliance not only on the appellants' unruliness but also on the reasoning that the picketing was being conducted at an improper situs, ${ }^{141}$ and that it was mentally distressing to the householder. ${ }^{142}$ If the "disorder" lay in these factors, then even peaceful picketing would constitute disorderly conduct..143

The questionable validity of such a classification is illustrated not only by judicial hesitancy to make it, ${ }^{144}$ but also by the fact situations it would encompass. Such a situation was presented in United Electrical Workers $v$. Baldwin. ${ }^{145}$ Witness also the following description of picketing of Mayor Daley's home in Chicago:

About 100 civil demonstrators file silently into the neighborhood. . . . No one jeers or hoots. No one says a word. [The neighborhood residents] . . . just stare, as if under command not to utter a sound-as, indeed, they are. Precinct workers ... circulate among them, shushing any talkers.

The marchers ... slowly walk around the Mayor's block, equally silent. Their cadres ... move up and down the lines whispering commands: "No talking, two-by-two, stay on the sidewalk, men on the outside."146

If a disorderly conduct or breach of the peace charge is leveled in such circumstances, it can only be because residential picketing per se is being equated with the offense. Such a policy judgment is more properly made in clear terms, rather than from behind the veil of

Supp. 1025 (Sup. Ct. 1936); Wick China Co. v. Brown, 164 Pa. 449, 30 Atl. 261 (1894); Murdock v. Walker, 152 Pa. 595, 25 Atl. 492 (1893).

141 The court in Perry felt that the "defendants were endeavoring to carry into the home and domestic life of Gustafson an industrial controversy which should have been left elsewhere." 196 Minn. at 482, 265 N.W. at 302.

142 The court in Zanker observed: "[The picketers] disregarded her right to be undisturbed. They resorted to offensive means. Their conduct necessarily carried some degree of humiliation and insult; it naturally tended to provoke resentment, not only on the part of Norma Christensen and her family, but also among the neighbors." 179 Minn, at 356-57, 229 N.W. at 311-12.

143 This equation was apparently made in State v. Cooper, 205 Minn. 333, 285 N.W. 903 (1939). After Dahl, a chauffeur and general houseman, was fired, his union authorized picketing of his former employer's residence. The defendant, one of the picketers, was convicted of disorderly conduct. The court affirmed, viewing the home as "a sanctuary of the individual." Id. at 336, 285 N.W. at 905. In view of Senn v. Tile Layers Union, 301 U.S. 468 (1937), in which a union was allowed to picket the residence-business of Senn, the Cooper decision is of dubious validity.

144 See, e.g., United Electrical Workers v. Baldwin, 67 F. Supp. 235 (D. Conn. 1946); People v. Levner, 30 N.Y.S.2d 487 (1941). But see State v. Cooper, 205 Minn. 333, 285 N.W. 903 (1939).

145 See text accompanying note 17 supra.

146 Wille, Mayor Daley Meets the Movement, The Nation, August 30, 1965, p. 92. See note 152 infra. 
a minor criminal charge: ${ }^{147}$ since the activity does have constitutional overtones, in that the rights of speech, assembly, and petition are being exercised, its proscription requires careful consideration. The lower courts' traditional reluctance to pass on constitutional questions ${ }^{148}$

147 Cf. Chafee, Free Speech in the United States $24-25$ (1948 ed.). The possibility of abuse of police and judicial discretion is one of the most serious indictments which may be leveled against loose disorderly conduct ordinances. An example of the problems is offered by those ordinances embodying language to the effect that a refusal to obey an order of a police officer to move on or disperse constitutes a violation of the law. See, e.g., N.Y. PEN. LAw \& 722(3). See also Clemmons v. CORE, 201 F. Supp. 737, 748 (1962); City of Tacoma v. Roe, 190 Wash. 444, 68 P.2d 1028 (1937). See generally 65 A.L.R.2d 1152 (1959). Such a provision might allow an officer to order residential picketers to move on, thus allowing their practice, in effect, to be regulated by his whim. Cf. Shuttlesworth v. City of Birmingham, 382 U.S. 87, 95 (1965). Contra, Chariton v. City of Fitzsimmons, 87 Iowa 226, 54 N.W. 146 (1893); People ex rel Frank v. Keeper of State Reformatory, 38 Misc. 233, 77 N.Y. Supp. 145 (Sup. Ct. 1902), aff'd People ex rel Frank v. Davis, 80 App. Div. 448, 80 N.Y. Supp. 872 (1903), to the effect that an order to move on cannot be made at the mere whim of the officer, but must be supported by the acts which inspired the order.

Moreover, since the courts often accept the officer's interpretation of the necessities for police action, conviction following a refusal to move on may well stand. As to the court's largely indiscriminate acceptance of officer's actions, see Cox v. Louisiana, 379 U.S. 536 (1965) (Black, J., concurring); Feiner v. New York, 340 U.S. 315 (1951); State v. Taylor, 38 N.J. Super. 6, 24-25, 30, 118 A.2d 36, 46, 48 (App. Div. 1955); People v. Galpern, 259 N.Y. 279, 181 N.E. 572 (1932). Contra, People v. Kieran, 6 Misc. 2d 245, 263, 26 N.Y.S.2d 291, 306 (Nassau County Ct. 1940); People v. Friedman, 6 Misc. 2d 271, 14 N.Y.S.2d 389, 392 (Magis. Ct. N.Y.C. 1939). Epitomizing the problem is People v. Galpern, 59 N.Y. 279, 181 N.E. 572 (1932), which is often approvingly cited. The defendant, a lawyer, had stopped on the street to talk briefy with some friends. Before they separated an officer approached and told them to move on; the defendant refused and was arrested and convicted of disorderly conduct. The court affirmed, even though it recognized that friends may stop on the sidewalk for a short conversation, and that in doing so they are not creating disorder or offending anyone or obstructing free passage. Even though such an order is unnecessary and ill-advised, it is not unauthorized. A refusal to obey is justifable only where the circumstances show conclusively that the officer's order was "purely arbitrary and was not calculated in any way to promote the public order." Id. at 284-85, 181 N.E. at 574. Such arbitrariness would appear to be very difficult to show, at least to the Galpern court, since it said: "The courts cannot weigh opposing considerations as to the wisdom of the police officer's directions when a police officer is called upon to decide whether the time has come in which some directions are called for." Id. at 285,181 N.E. at 574.

It is true that in Wright v. Georgia, 373 U.S. 284 (1963), the Court, in reversing the conviction of Negro youths who had refused an officer's order to leave a whites-only basketball court said: "One cannot be punished for failing to obey the command of an officer if that command is itself violative of the Constitution." Id. at 291-92. However, the command was violative in Wright because the petitioners had a right to use the basketball court. It remains to be determined whether residential picketers are pursuing a constitutional right. Certainly, if they are not, there are more suitable ways to establish this than by the affirmance of a disorderly conduct conviction for a refusal to move onviz., legislative determination.

148 See People v. Levner, 30 N.Y.S.2d 487 (Magis. Ct. N.Y.C. 1941); Barrett, Avoidance of Judicial Decision Upon Constitutional Ground When Decision Can Be Based Upon Other Ground, 28 ORE. L. REv. 201 (1949). 
may lead them to emphasize the severity of disorder, thereby avoiding treatment of residential picketing as a distinct event. ${ }^{149}$ Moreover, even if close analysis may reveal that a policy judgment is sometimes being made-albeit sub silentio-when residential picketers are convicted of disorderly conduct, the use of such a sanction obscures this judgment. ${ }^{150}$ The potential picketer is thus left in doubt as to whether prior dispositions turned on the question of actual disorder, or on the event of the picketing itself. 151

It is perhaps unreasonable, however, to suppose that residential picketing will always be peaceful. If the picketers are orderly, then police action may be inspired by the presence of a hostile audience, ${ }^{162}$

149 This is perhaps a proper framework in which to reconcile Levner, which emphasized the disorder and thus dismissed the constitutional arguments, with Flores, which minimized the unruliness and turned to the constitutional issues.

150 Cf., Note, Non-Labor Picketing, 41 Conum. L. REv. 89, 94 (1941).

151 Cf., Lanzetta v. New Jersey, 306 U.S. 451, 453 (1939); Connally v. General Constr. Co., 269 U.S. 385, 391 (1926), involving vague penal statutes. See generally Amsterdam, The Void-for-Vagueness Doctrine in the Supreme Court, 109 U. PA. L. REv. 67 (1960).

152 Such a situation is illustrated in Gity of Chicago v. Gant, Chicago Munic. Ct. No. 585,798 (1965), an unreported decision. See discussion of this case in Kamin, Picketing 177-82, 231-36. On August 1-5, 1965, a group picketed Mayor Daley's home in Chicago to protest the rehiring of the superintendent of schools. See note 3 supra. Despite the peacefulness of the picketers, they were ordered to disperse because of the spectators' hostile reaction. The picketers refused and some of them were arrested. (This occurred two nights prior to the peaceful situation depicted in the Wille article, supra note 146.) They were subsequently convicted of disorderly conduct. Chicago Daily News, Nov. 13, 1965, p. 6, col. 8, and Nov. 12, 1965, p. 17, cols. 2-5. The following is a portion of the transcript of the trial, presenting a part of the dialogue between the defense attorney and a police officer at the scene:

Q. At 35 th and Lowe, at the time of Commander Pierson's statement that conditions were riotous, what, if anything, were the marchers doing?

A. They were standing there on the sidewalk.

$\mathrm{Q}$. Were they singing?

A. Not at that time.

Q. Were they chanting?

A. No, ma'am.

Q. Were they noisy?

A. No, ma'am.

Q. Were they shouting?

A. No, ma'am.

Q. Were they throwing rocks?

A. No, ma'am.

Q. Were they throwing eggs?

A. No, ma'am.

Q. ... Were the spectators shouting?

A. Yes, ma'am.

Q. Were they noisey? (sic).

A. Yes, ma'am.

Q. ... Were they throwing eggs?

A. Yes, ma'am.

Q. Were they throwing rocks?

A. Yes, ma'am.

Q. Were they shouting epithets such as, "Go home, nigger."

A. They were shouting. I couldn't honestly say they were shouting that.

Record, pp. 135-37, City of Chicago v. Gant, Chicago Munic. Ct. No. 585,798 (1965). 
for the typical interpretation of disorderly conduct ordinances is that "conduct is disorderly, in the ordinary sense, when it is of such nature as to affect the peace and quiet of persons who may witness the same and who may be disturbed or provoked to resentment thereby."153

A steadily growing line of decisions, however, indicates that peaceful picketers should not be arrested for disorderly conduct or breach of the peace on the basis of a hostile audience's reaction. ${ }^{154}$ In the first Cox decision, ${ }^{155}$ the Court reversed Cox's conviction for disturbing the peace, reading the evidence as showing no indication of threatened violence by the spectators who had gathered at the demonstration scene. Even conceding, however, that the presence of police might be necessary because of the unpopularity of the marchers' activity, "constitutional rights may not be denied simply because of hostility as to their assertion or exercise." 156 Thus, even though the First and Fourteenth Amendments do not "afford the same kind of freedom" to non-labor picketing as they do to pure speech, ${ }^{157}$ non-labor picketing is of sufficient constitutional stature as to preclude its abridgement solely on the basis of a hostile audience reaction. ${ }^{158}$

\section{The Administrative Approach-Licensing}

Licensing of speech and speech-associated activities has long been condemned as a form of prior restraint. ${ }^{159}$ Nonetheless, at least one

153 State v. Zanker, 179 Minn. 355, 357, 229 N.W. 311, 312 (1936).

154 The leading decision is Terminiello v. City of Chicago, 337 U.S. 1 (1949). Terminiello had delivered an anti-Semitic speech in a private hall. Outside, an angry crowd gathered. Terminiello was arrested and convicted for disorderly conduct. The Court reversed this conviction on the basis of an improper jury instruction, but it went on to characterize his actions as protected speech. See generally Note, 49 Colum. L. REv. 1118 (1949); Note, Derbal Acts and Ideas: The Common Sense of Free Speech, 16 U. CHI. L. Rev. 328 (1949).

In Feiner v. New York, 340 U.S. 315 (1950), the Court, while mindful that the presence of a hostile audience cannot silence a speaker, upheld a disorderly conduct conviction because the "speaker [passed] the bounds of argument or persuasion and [had undertaken] incitement to riot." Id. at 321.

155379 U.S. 536 (1965).

$156 I d$. at 551, citing Watson v. City of Memphis, 373 U.S. 526, 535 (1963).

157 See quotation accompanying note 34 supra.

158 See also Milk Wagon Drivers Union v. Meadowmoor Dairies, 312 U.S. 287, 296 (1941) (involving labor picketing); Allen v. District of Columbia, 187 A.2d 888 (D.C. Ct. App. 1963). The Terminiello rationale has been applied to other non-pure speech situations as well. See, e.g., Barr v. City of Columbia, 378 U.S. 146 (1964); Wright v. Georgia, 373 U.S. 284 (1963); Nesmith v. Alford, 318 F.2d 110, 120-21 (5th Cir. 1963).

Just as a hostile audience will not justify the arrest of peaceful demonstrators, the courts cannot enjoin persons from engaging in lawful activities on the sole ground that others may react to the activities unlawfully and violently. See, e.g., Cooper v. Aaron, 358 U.S. I (1958); CORE v. Douglas, 318 F.2d 95 (5th Cir. 1963). Contra, United States v. U.S. Klans, Knights of Ku Klux Klan, Inc., 194 F. Supp. 897 (M.D. Ala. 1961).

159 See generally Emerson, The Doctrine of Prior Restraint, 20 LAW \& ConTEMP. ProB. $648,660-69$ (1955). 
commentator on the public forum has suggested that "the judgments of time, place, and manner required must be so linked to the factual situation as to make detailed legislative regulation a clumsy, inflexible device." 160 Thus, he proposes licensing as a tenable system for control of the use of the streets. However, a licensing system is unnecessary to deal with residential picketing. Since use of the residential situs is uniformly improper, except where the office is in the home, ${ }^{161}$ no occasion would arise for the exercise of administrative discretion. While considerations of time, place, and manner may be so complex as to make the traditional balancing formula an awkward approach to the public forum, these considerations are not troublesome when residential picketing is analyzed. The number of picketers, the time of day, the intensity of traffic, and other variables of time and manner do not alter the character of the private residence as unsuitable for protest activity.

\section{Legislative Determination-A Narrowly Drawn Statute}

If residential picketing is to be prohibited, it is a narrowly drawn statute which should be utilized to achieve this end. Even in Edwards v. South Carolina, where the Court was clearly impressed with the demonstration as "an exercise of . . . basic constitutional rights,"162 it might have taken a different view had there been the "evenhanded application of a precise and narrowly drawn regulatory statute evincing a legislative judgment that certain specific conduct be limited or proscribed." 183 The second Cox decision, as well, reveals the strong deference accorded such a law. The legislative determination there gave prohibition of courthouse picketing an imprimatur of constitutionality it might not otherwise have had.

Several state legislatures have enacted statutes relating to residential picketing. Most of these are directed towards labor activity and declare it to be an unfair labor practice subject to the courts' or state employment relations boards' injunctive powers. ${ }^{164}$ One state, Hawaii,

160 Kalven, The Public Forum 28-29.

161 See note 78 supra.

162372 U.S. 229, 235 (1963).

163 Id. at 236. Cf. Cantwell v. Connecticut, 310 U.S. 296, 307-08 (1940).

164 See, e.g., Colo. Rev. Stat. ANn. § 80-4-6(2)(b) (1963); Conn. Gen Stat. AnN. 31-120 (1960); Fla. Stat. ANN., § 447.09(11) (1952); Kan. Gen. Stat. ANn. § 44-809(12) (1949); Mich. StAT. ANN. \& 17.454(10.5) (1960); NEB. REv. StAT. 28-812(6) (1965); S.D. CoDE \& 17.1107 (Supp. 1960) (no picketing of homes on agricultural premises); UTAF CODE ANN 34-1 8(2)(a) (1953); WIs. STAT. ANN. 111.06(2)(a) (1957).

The National Labor Relations Act, 29 U.S.C. 158(b)(1)(A) (1965), is also applicable, as ruled in Meat Cutters, Local 150-F, United Mechanics' Union (American Photocopy Equipment Co.), 151 N.L.R.B. No. 33, 58 L.R.R.M. 1413 (1965).* Residential picketing may, however, be enjoined by the states where it is violent, UAW v. Wisconsin Employment Rela- 
makes residential picketing in any context a criminal offense. ${ }^{165}$ Other states have banned picketing of the homes of judges, jurors, witnesses, or court officers. ${ }^{160}$ Arizona, on the other hand, sanctions labor residential picketing. ${ }^{167}$ While the courts have seldom confronted such statutory provisions, the Supreme Court has on at least three occasions given passing approval to a labor statute declaring such picketing an unfair labor practice. ${ }^{168}$

In prohibiting non-labor residential picketing, the state or municipality would be exercising its well recognized powers to regulate the use of the streets and other public places. ${ }^{109}$ Usually, when an ordinance or statute implementing those powers has been struck down as unconstitutional, the decision has turned on the excessive breadth of the ordinance $^{170}$ or on the issue of prior restraint. ${ }^{171}$ Neither problem

tions Bd., 351 U.S. 266, 272 (1956), or even peaceful, State v. Macelwane, 116 Ohio App. 183, 195, 187 N.E.2d 901, 908 (1961).

165 HAWAII REv. LAws § 300-1,2,3 (1955) Picketing of Residence or Dwelling Place. 300-1. Declarations of legislature. It is hereby declared that the protection and preservation of the home is the keystone of democratic government; that the public health and welfare and good order of the community require that members of the community enjoy in their homes a feeling of well-being, tranquility, and privacy, and when absent from their homes carry with them the sense of security inherent in the assurance that they may return to the enjoyment of their homes; that the practice of picketing before or about residences and dwelling places causes emotional disturbance and distress to the occupants; that such practice has as its object the harassing of such occupants and, without resort to such practice, full opportunity exists, and under the terms and provisions of this chapter will continue to exist, for the exercise of freedom of speech and other constitutional rights; and that the provisions hereinafter enacted are necessary to the public interest, to avoid the detrimental results herein set forth. . . .

300-2. Picketing of residence or dwelling prohibited. It shall be unlawful for any person to engage in picketing before or about the residence or dwelling place of any individual. Nothing herein shall be deemed to prohibit (a) the picketing in any lawful manner, during a labor dispute, of the place of employment involved in such labor disputes; or (b) the holding of a meeting or assembly on any premises used for the discussion of subjects of general public interest. . . . 300-3. Penalty. Any Person violating section 300-2 shall be fined not more than $\$ 200$ or imprisoned not more than six months, or both. . . .

166 See, e.g., LA. Rev. Stat. § 14:101 (Cum. Supp. 1965); PA. Stat. AnN. tit. 18, § 4327 (1963).

167 ARIz. REv. Stat. § 12-1808 B.2. (1956):

B. The preliminary injunction or temporary restraining order ... shall not prohibit any person from:

...

2. Attending at or near a house or place where any person resides or works, or carries on business, or happens to be, for the purpose of peacefully obtaining or communicating information, or of peacefully persuading any person to work or to abstain from working.

168 UAW v. Wisconsin Employment Relations Bd., 351 U.S. 266, 274 (1956); Garner v. Teamsters Union, 346 U.S. 485, 488 (1953); Allen Bradley Local 1111 v. Wisconsin Employment Relations Bd., 315 U.S. 740,749 (1942).

169 For partial listing see 37 NEB. L. REv. 479 (1958).

170 Cox v. Louisiana, 379 U.S. 536 (1965); Edwards v. South Carolina, 372 U.S. 229 (1963); Saia v. New York, 334 U.S. 558 (1948); Schneider v. State, 308 U.S. 147 (1939); Hague v. CIO, 307 U.S. 496 (1939); Lovell v. City of Griffin, 303 U.S. 444 (1938).

171 Kunz v. New York, 340 U.S. 290 (1951); Niemotko v. Maryland, 340 U.S. 268 (1951); Saia v. New York, 334 U.S. 558, 560 (1948); Thomas v. Collins, 323 U.S. 516, 540 (1945); 
would be present here. Prohibition could take the form suggested by Professor Emerson, writing of the possibilty of regulation aimed at protecting homeowners' privacy:

The restriction can be couched in terms of a limitation on ... geographical area, . . . or the allocation of space in the public park system. No element of prohibition or regulation of the content of the communication is involved.172

The Hawaii statute, in fact, affords an excellent model from which to work.

Of course, even a legislative solution will not remedy all the problems which residential picketing raises. In terms of form, the statute would have to include a caveat allowing picketing of homes in which the office is located. ${ }^{173}$ Here the need for access to the official would probably override the disruptive factors of the activity. As for interpretation of the statute, to fall within the ambit of the offense a specific home would have to be the target of the protest, lest general neighborhood marches be unwarrantedly halted. This may not always be easily discernible. Professor Kamin, in his work on residential picketing, notes that after several days of protests during which it was clear that the home of Chicago's Mayor Daley was the target of the marches, the rhetoric of the demonstrators changed to a protest against the segregation of the entire neighborhood within which they were parading. ${ }^{174}$ A variation of this problem is suggested by the same series of demonstrations. The marchers did not remain before the mayor's home, but paraded around the block on which he lived. Whether a march whose perimeters enclosed four square blocks, instead of one, could be considered as directed against a target residence would depend upon factual determinations, such as the nature of the grievance and the statements of the group. At some point, it would seem clear, the picketing, even if denouncing a specific individual, would not fall within the sphere of the proposed statute.

Another problem in prohibiting all non-labor residential picketing exists because much of the argument in favor of the practice is tempered by the official's public character, and the consequent ease of access to the communications media. However, the target of picketers might be a relatively unknown individual. Probably the best example of this, and

\footnotetext{
Hague v. CIO, 307 U.S. 496 (1939); Lovell v. City of Griffin, 303 U.S. 444, 451 (1938). See generally Emerson, The Doctrine of Prior Restraint, 20 LAw \& CONTEMP. PROB. 649, 664-67 (1955).

172 Emerson, Toward a General Theory of the First Amendment, 72 YALE L.J. 877, 927 (1963).

173 See note 78 supra.

174 Kamin, Picketing 181.
} 
one whose home is frequently beset by residential picketers, is the slumlord, ${ }^{175}$ who often actively seeks anonymity. While exposure of such lesser-known people may be welcome, and often efficacious, ${ }^{176}$ residential picketing remains a questionable tactic. At least in the case of unwarranted housing practices, protests directed to the proper municipal agencies, ${ }^{177}$ and enforcement and improvement of present housing codes, appear to be the proper solutions. True, there will still be some intra-party disputes which cannot be resolved by resort to such agencies and legislation. But the merits of residential picketing, when measured against its drawbacks, do not commend this practice as the means to publicize otherwise obscure conflicts.

\section{CONCLUSION}

Residential picketing is a regrettable tactic in the armament of protesters. Nevertheless, it is a constitutionally colored activity-it partakes of the rights of speech, assembly, and petition. This characterization, plus the absence of precedents which are dispositive, requires a careful analysis of the feasibility of proscription.

The practice of residential picketing exerts "injuries" upon the homeowner-public official, making of him and his family a captive audience and intruding into the enjoyment and privacy of their home. In weighing the benefits of the residential situs against the detriments, the argument for prohibition of residential picketing is strongest, since only by such prohibition can the homeowner's interests be protected. Undeniably, prohibition of residential picketing would work to the detriment of the picketer: he would lose a forum which affords him economy, publicity, and effectiveness. These benefits are not completely lost; they can be largely approximated elsewhere. Thus prohibition, its detriments mitigated by the availability of other demonstration sites, offers the most tenable compromise.

Nuisance law, the tort law of privacy, and minor criminal sanctions such as those for disorderly conduct are not suited to effect this prohibition. A narrowly drawn statute is necessary. It would evince the considered legislative judgment necessary to resolve the issues which residential picketing raises, while at the same time it would clearly forewarn the potential picketer.

175 See Chicago Sun-Times, March 14, 1966, p. 28, cols, 1-3; Chicago Sun-Times, May 9, 1966, p. 10, cols. 2-3; Chicago Daily News, Sept. 12, 1966, p. 9, cols. 1-2.

176 See Silberman, Crisis in Black and Whrte 330 (1964).

177 Cf. Springfield, Bayside Corp. v. Hochman, 44 Misc. 2d 882, 255 N.Y.S.2d 140 (Sup. Ct. 1964); People v. Kopezak, 153 Misc. 187, 274 N.Y.S. 629 (Sup. Ct.), aff d, 266 N.Y. 565, 195 N.E. 202 (1934). 